\title{
Greenland liquid water discharge from 1958 through 2019
}

\author{
Kenneth D. Mankoff ${ }^{1}$, Brice Noël $^{2}$, Xavier Fettweis ${ }^{3}$, Andreas P. Ahlstrøm ${ }^{1}$, William Colgan ${ }^{1}$, \\ Ken Kondo $^{4}$, Kirsty Langley ${ }^{5}$, Shin Sugiyama ${ }^{4}$, Dirk van $\mathrm{As}^{1}$, and Robert S. Fausto ${ }^{1}$ \\ ${ }^{1}$ Department of Glaciology and Climate, Geological Survey of Denmark and Greenland (GEUS), \\ Copenhagen, Denmark \\ ${ }^{2}$ Institute for Marine and Atmospheric Research, Utrecht University, Utrecht, the Netherlands \\ ${ }^{3}$ SPHERES research unit, Department of Geography, University of Liège, Liège, Belgium \\ ${ }^{4}$ Institute of Low Temperature Science, Hokkaido University, Sapporo, Japan \\ ${ }^{5}$ Asiaq - Greenland Survey, Nuuk, Greenland \\ Correspondence: Kenneth D. Mankoff (kdm@geus.dk)
}

Received: 26 February 2020 - Discussion started: 7 April 2020

Revised: 22 October 2020 - Accepted: 28 October 2020 - Published: 14 November 2020

\begin{abstract}
Greenland runoff, from ice mass loss and increasing rainfall, is increasing. That runoff, as discharge, impacts the physical, chemical, and biological properties of the adjacent fjords. However, where and when the discharge occurs is not readily available in an open database. Here we provide data sets of highresolution Greenland hydrologic outlets, basins, and streams, as well as a daily 1958 through 2019 time series of Greenland liquid water discharge for each outlet. The data include 24507 ice marginal outlets and upstream basins and 29635 land coast outlets and upstream basins, derived from the $100 \mathrm{~m}$ ArcticDEM and $150 \mathrm{~m}$ BedMachine. At each outlet there are daily discharge data for $22645 \mathrm{~d}$ - ice sheet runoff routed subglacially to ice margin outlets and land runoff routed to coast outlets - from two regional climate models (RCMs; MAR and RACMO). Our sensitivity study of how outlet location changes for every inland cell based on subglacial routing assumptions shows that most inland cells where runoff occurs are not highly sensitive to those routing assumptions, and outflow location does not move far. We compare RCM results with 10 gauges from streams with discharge rates spanning 4 orders of magnitude. Results show that for daily discharge at the individual basin scale the $5 \%$ to $95 \%$ prediction interval between modeled discharge and observations generally falls within plus or minus a factor of 5 (half an order of magnitude, or $+500 \% /-80 \%$ ). Results from this study are available at https://doi.org/10.22008/promice/freshwater (Mankoff, 2020a) and code is available at http://github.com/mankoff/freshwater (last access: 6 November 2020) (Mankoff, 2020b).
\end{abstract}

Over the past decades, liquid runoff from Greenland has increased (Mernild and Liston, 2012; Bamber et al., 2018; Trusel et al., 2018; Perner et al., 2019), contributing to mass decrease (Sasgen et al., 2020). When that runoff leaves the ice sheet and discharges into fjords and coastal seas, it influences a wide range of physical (Straneo et al., 2011; An et al., 2012; Mortensen et al., 2013; Bendtsen et al., 2015; Cowton et al., 2015; Mankoff et al., 2016; Fried et al., 2019; Cowton et al., 2019; Beckmann et al., 2019), chemical (Kanna et al., 2018; Balmonte et al., 2019), and biological (Kamenos et al., 2012; Kanna et al., 2018; Balmonte et al., 2019) systems (Catania et al., 2020). The scales of the impacts range from instantaneous at the ice-ocean boundary to decadal in the distal ocean (Gillard et al., 2016). The influence of freshwater on multiple domains and disciplines (Catania et al., 2020 ) is the reason several past studies have estimated runoff and discharge at various temporal and spatial scales (e.g., Mernild et al., 2008, 2009; Mernild et al., 2010a; Langen et al., 2015; Ahlstrøm et al., 2017; Citterio et al., 2017; van As et al., 2018; Bamber et al., 2018; Perner et al., 2019; Slater et al., 2019). 
To date no product provides discharge estimates at high spatial resolution $(\sim 100 \mathrm{~m}$; resolving individual streams), daily temporal resolution, for all of Greenland, covering a broad time span (1958 through 2019), from multiple regional climate models (RCMs), and with a simple database access software to support downstream users. Here we present these data. In the following description and methods, we document the inputs, assumptions, methodologies, and results we use to estimate Greenland discharge from 1958 through 2019.

Freshwater discharge from Greenland primarily takes three forms: solid ice from calving at marine-terminating glaciers; submarine meltwater from ice-ocean boundary melting at marine-terminating glaciers; and liquid runoff from melted inland surface ice, rain, and condensation. A recent paper by Mankoff et al. (2020) targets the solid ice discharge plus submarine melt budget by estimating the ice flow rate across gates $5 \mathrm{~km}$ upstream from all fast-flowing marineterminating glaciers in Greenland. Complementing that paper, this paper targets Greenland's point-source liquid water discharge budget by partitioning RCM runoff estimates to all ice margin and coastal outlets. The sum of these data and Mankoff et al. (2020) is an estimate of the majority of freshwater (in both liquid and solid form) volume flow rates into Greenland fjords. Those two terms comprise the bulk but not all freshwater - they exclude precipitation directly onto the fjord or ocean surface, as well as relatively minor contributions from evaporation and condensation, sea ice formation and melt, or subglacial basal melting.

\section{Input and validation data}

\subsection{Static data}

The static products (streams, outlets, and basins; Fig. 1) are derived from an ice sheet surface digital elevation model (DEM), an ice sheet bed DEM, an ice sheet mask, the land surface DEM, and an ocean mask. For the surface DEM, we use ArcticDEM v7 $100 \mathrm{~m}$ (Porter et al., 2018). Subglacial routing uses ArcticDEM and ice thickness from BedMachine v3 (Morlighem et al., 2017a,b). Both DEMs are referenced to the WGS84 ellipsoid. For the ice mask we use the Programme for Monitoring of the Greenland Ice Sheet (PROMICE) ice extent (Citterio and Ahlstrøm, 2013). For the ocean mask we use the Making Earth System Data Records for Use in Research Environments (MEaSUREs) Greenland Ice Mapping Project (GIMP) Land Ice and Ocean Classification Mask, Version 1 (Howat, 2017b; Howat et al., 2014).

\subsection{RCM time series}

The time series product (daily discharge) is derived from daily runoff estimates from RCM calculations over the land and ice areas of Greenland. We use the Modèle Atmosphérique Régional (MAR; Fettweis et al., 2017) and the Re-

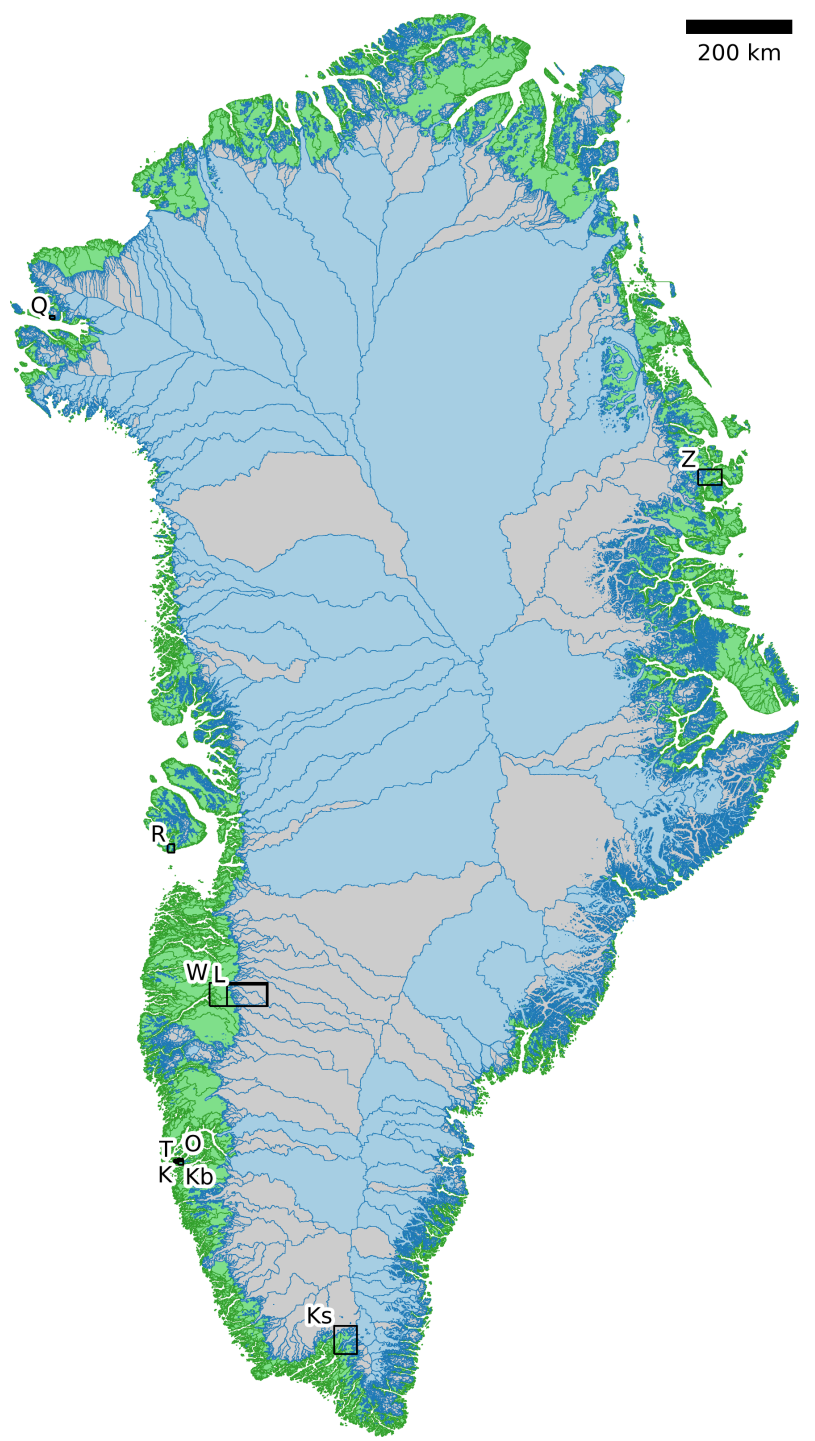

Figure 1. Overview. Map of Greenland showing all basins and the location of 10 gauged streams used for comparison. Land basins are shown in green. Ice basins are shown in blue when outlet elevation $<0$ and gray when outlet elevation $\geq 0$ (outlet error elevation is discussed in Sect. 4.3.6). Black boxes and labels mark the location of stream gauge observation locations (see Table 1).

gional Atmospheric Climate Model (RACMO; Noël et al., 2019). Runoff, $R$, is defined by

$R=\mathrm{ME}+\mathrm{RA}-\mathrm{RT}-\mathrm{RF}$.

In Eq. (1), ME is melt, RA is rainfall, $\mathrm{RT}$ is retention, and $\mathrm{RF}$ is refreezing. In RACMO, retention occurs only when firn is present (not with bare ice). MAR does have a delay for bare ice runoff. Neither have a delay for land runoff. Both RCM outputs were provided regridded to the same $1 \mathrm{~km}$ grid using an offline statistical downscaling technique based on the local vertical runoff gradient applied to the subgrid topography (Noël et al., 2016; Fettweis et al., 2020). MAR (v 3.11; 
Delhasse et al., 2020) ran with $7.5 \mathrm{~km}$ resolution and ERA5 $6 \mathrm{~h}$ forcing. RACMO (v 2.3p2; Noël et al., 2018, 2019) ran with $5.5 \mathrm{~km}$ resolution and ERA-Interim $6 \mathrm{~h}$ forcing. Runoff is assigned an uncertainty of $\pm 15 \%$ (Sect. 4.3.3).

\subsection{River discharge observations}

We use 10 river discharge daily time series to validate the results of this work. The name, location, time coverage, and relevant data and scientific publications associated with each of these observational data are listed in Table 1.

\section{Methods}

\subsection{Terminology}

We use the following terminology throughout the document:

- Runoff refers to the unmodified RCM data products melted ice, rain, condensation, and evaporation - that comprise the RCM runoff output variable.

- Discharge refers to the runoff after it has been processed by this work - routed to and aggregated at the outlets. Depending on context, discharge may also refer to the observed stream discharge (Table 1).

- Basins refer to the $100 \mathrm{~m} \times 100 \mathrm{~m}$ gridded basins derived from a combination of the ArcticDEM product and the mask.

- Mask refers to the surface classification on that $100 \mathrm{~m} \times 100 \mathrm{~m}$ grid and is one of ice, land, or ocean (also called fjord or water). When referring to the surface classification in the RCM, we explicitly state "RCM mask".

- MAR and RACMO refer to the RCMs, but when comparing discharge estimates between them or to observations, we use MAR and RACMO to refer to our discharge product derived from the MAR and RACMO RCM runoff variables rather than repeatedly explicitly stating "discharged derived from [MARIRACMO] runoff". The use should be clear from context.

\subsection{Streams, outlets, and basins}

Streams are calculated from the hydraulic head $h$, which is the DEM surface for land surface routing, or the subglacial pressure head elevation for subglacial routing. $h$ is defined as

$h=z_{\mathrm{b}}+k \frac{\rho_{\mathrm{i}}}{\rho_{\mathrm{w}}}\left(z_{\mathrm{s}}-z_{\mathrm{b}}\right)$,

with $z_{\mathrm{b}}$ the ice-free land surface and basal topography, $k$ the flotation fraction, $\rho_{\mathrm{i}}$ the density of ice $\left(917 \mathrm{~kg} \mathrm{~m}^{-3}\right), \rho_{\mathrm{w}}$ the density of water $\left(1000 \mathrm{~kg} \mathrm{~m}^{-3}\right)$, and $z_{\mathrm{s}}$ the land surface for both ice-free and ice-covered surfaces.
Equation (2) comes from Shreve (1972), where the hydropotential has units of pascals $(\mathrm{Pa})$, but here it is divided by gravitational acceleration $g$ times the density of water $\rho_{\mathrm{W}}$ to convert the units from pascals to meters ( $\mathrm{Pa}$ to $\mathrm{m}$ ). We compute $h$ and from that streams, outlets, basins, and runoff for a range of subglacial pressures, implemented as a range of $k$ values: $0.8,0.9$, and 1.0. We use these three scenarios to estimate sensitivity of the outlet location for all upstream cells but otherwise only use results from the $k=1.0$ scenario. Equation (2) makes the assumption that when ice is present all water routes subglacially, meaning that water flows from the surface to the bed in the grid cell where it is generated. In reality, internal catchments and moulins likely drain waters to the bed within a few kilometers of their source (Yang and Smith, 2016). The difference between some supraglacial flow and immediate subglacial flow is not likely to impact results because discharge is reported only at the outlet locations.

We use the GRASS GIS software (Neteler et al., 2012; GRASS Development Team, 2018) and the r.stream. extract command configured for singleflow direction from eight neighbors (SFD-8) to calculate streams and outlets at the ice edge and coast. Streams are defined only if their upstream contributing area is above a threshold $\left(>3 \mathrm{~km}^{2}\right)$, so small basins may have outlets but no streams. The software fills all sinks so that all water flows to the domain edge. We then use the r.stream.basins tool (Jasiewicz and Metz, 2011) to calculate basins upstream from each outlet. Basins $<1 \mathrm{~km}^{2}$ are absorbed into their largest neighbor and the associated outlets are dropped.

\subsubsection{Outlet sensitivity}

The three choices of $k$ generate three scenarios of basins and outlets, and we use this to show sensitivity of every ice grid cell to these choices. After three $k$ scenarios, each cell has three possible outlets, where each outlet is an $(x, y)$ coordinate. To show results in a map view, we reduced these six properties (three 2D coordinates) to a single property. For every grid cell in the ice domain we compute the maximum distance between each outlet and the other two (six becomes three), and we then select the maximum (three becomes one). Figure 2 displays the maximum distance - a worst-case scenario - of how far the outlet of every inland ice cell may move due to basal routing assumptions.

\subsection{Discharge and RCM coverage}

$\mathrm{RCM}$ runoff is summed over each basin for each day of RCM data and assigned to each outlet for that day. This assumes routing between the runoff and the outlet is instantaneous, so all analyses done here include a $7 \mathrm{~d}$ smooth applied to the RCM discharge product (cf. van As et al., 2017). The released data do not include any smoothing.

The alignments of the RCM and the basins do not always agree. Each $100 \mathrm{~m} \times 100 \mathrm{~m}$ ArcticDEM pixel is classified as 
Table 1. Table of observation locations, time spans, and associated references. Coordinates are decimal degree W and N.

\begin{tabular}{lrrrll}
\hline Location & Long & Lat & Time & Data & Publication \\
\hline Kiattuut Sermiat & 45.33 & 61.21 & 2013 & Hawkings et al. (2016a) & Hawkings et al. (2016b) \\
Kingigtorssuaq (Nuuk) & 51.5801 & 64.1387 & $2008-2018$ & Langley (2020) & \\
Kobbefjord (Nuuk) & 51.3810 & 64.1336 & $2006-2017$ & Langley (2020) & 13411 \\
Leverett Glacier & 50.17 & 67.06 & $2009-2012$ & Tedstone et al. (2017) & Hawkings et al. (2015) \\
Oriartorfik (Nuuk) & 51.4066 & 64.1707 & $2007-2018$ & Langley (2020) & \\
Qaanaaq & 69.3030 & 77.4753 & $2017-2018$ & Kondo and Sugiyama (2020) & Sugiyama et al. (2014) \\
Røde Elv (Disko) & 53.4989 & 69.2534 & 2017 & Langley (2020) & 134517 \\
Teqinngalip (Nuuk) & 51.5484 & 64.1586 & $2007-2018$ & Langley (2020) & 1345615 \\
Watson River & 50.68 & 67.01 & $2006-2019$ & van As et al. (2018) & van As et al. (2018) \\
Zackenberg & 20.5628 & 74.4722 & $1996-2018$ & Langley (2020) & 134578 \\
\hline
\end{tabular}

ice (Citterio and Ahlstrøm, 2013), ocean (Howat, 2017b), or land (defined as neither ice nor ocean). However, the classification of the mask cells and the $1 \mathrm{~km}^{2} \mathrm{RCM}$ domains do not always agree - for example, when a mask cell is classified as ice but the matching RCM cell is land. This disagreement occurs almost everywhere along the ice margin because the $1 \mathrm{~km}$ RCM boundary and the $100 \mathrm{~m}$ mask boundary rarely perfectly align. The ice margin is where most runoff occurs per unit area due to the highest temperatures at the lowest ice elevations, so small changes in masks in these locations can introduce large changes in RCM outputs.

We adjust for this imprecise overlap and scale the RCM results to the basin area. Where the mask reports ice and a RCM reports land, the RCM land runoff fraction is discarded, and the RCM ice runoff fraction over this basin is adjusted for the uncovered basin cells (and vice versa for basin land and RCM ice). Small basins with no RCM coverage of the same type have no runoff.

Runoff adjustments using this method are underestimated for large basins with large inland high-elevation regions with low runoff, because this method fills in misaligned cells with each day's average discharge, but the misalignment (missing runoff) occurs at the ice sheet edge where maximum runoff occurs. However, given that the basin is large, misalignment is proportionally small, and therefore errors are proportionally small. Conversely, when misalignment is proportionally large (e.g., a basin is only $1 \%$ covered by the same RCM classification), this implies a small basin. Because the basin is small, the covered region (no matter how much smaller) must be nearby and not climatically different.

RCM inputs are also scaled to adjust for the EPSG:3413 non-equal-area projection. This error is up to $8 \%$ for some grid cells but ranges from $-6 \%$ to $+8 \%$ over Greenland, and the cumulative error for the entire ice sheet is $<8 \%$.

\subsection{Validation}

We validate the modeled outlet discharge against the observations first in bulk and then individually. Bulk comparisons are done with scatter plots (Figs. 3 and 4 ) and modified Tukey plots comparing observations vs. the ratio of the RCMs to observations (Fig. 5, based on Tukey mean-difference plots, also known as Bland-Altman plots; Altman and Bland, 1983; Martin Bland and Altman, 1986).

We introduce the graphics here as part of the methods to reduce replication in figure captions - we show 10 nearly identical graphics (Figs. 7 and 9 through 17) for 10 different observation locations, and each graphic uses the same template of six panels.

For each figure (Figs. 7 and 9 to 17), the top panel (a) shows a satellite basemap with the land portion of the basin of interest (if it exists) outlined in dark green, the streams within that basin in light green, the basin outlet as an orange filled diamond, and the stream gauge location as an orange unfilled diamond. Ice basin(s) that drain to the outlet are outlined in thick dark blue if they exist, and all other ice basins are outlined in thin dark blue. Both MAR and RACMO use the same domains. The RCM ice domain is in light blue, and the RCM land domain is not shown but is outside the light blue ice domain (not including the water). The scale of each map varies, but the basin lines (green and dark blue) are on a $100 \mathrm{~m}$ grid, and the RCM grid cells (light blue) are on a $1 \mathrm{~km}$ grid.

Panel (b) shows an example time series - whatever data are available for the last calendar year of the observations.

Panel (c) shows a scatter plot of observations vs. RCMderived discharge. This is the same data shown in Fig. 3 but subset to just the basin of interest. Color encodes day of year, and a kernel density estimation (KDE) of the discharge highlights where most points occur - not necessarily visible without the KDE because the points overlap (total number of plotted points is printed on the graphic near "n:"). The $r^{2}$ correlation coefficient for each RCM-derived discharge is displayed. The gray band shows the $5 \%$ to $95 \%$ prediction interval, and the three solid lines mark the $1: 1,1: 5$, and $5: 1$ ratios.

Panel (d) shows observations vs. the ratio of the RCM to the observations. This is the same data shown in Fig. 5 but subset to just the basin of interest. Color denotes sample density (similar to the KDE in panel c). The horizontal 


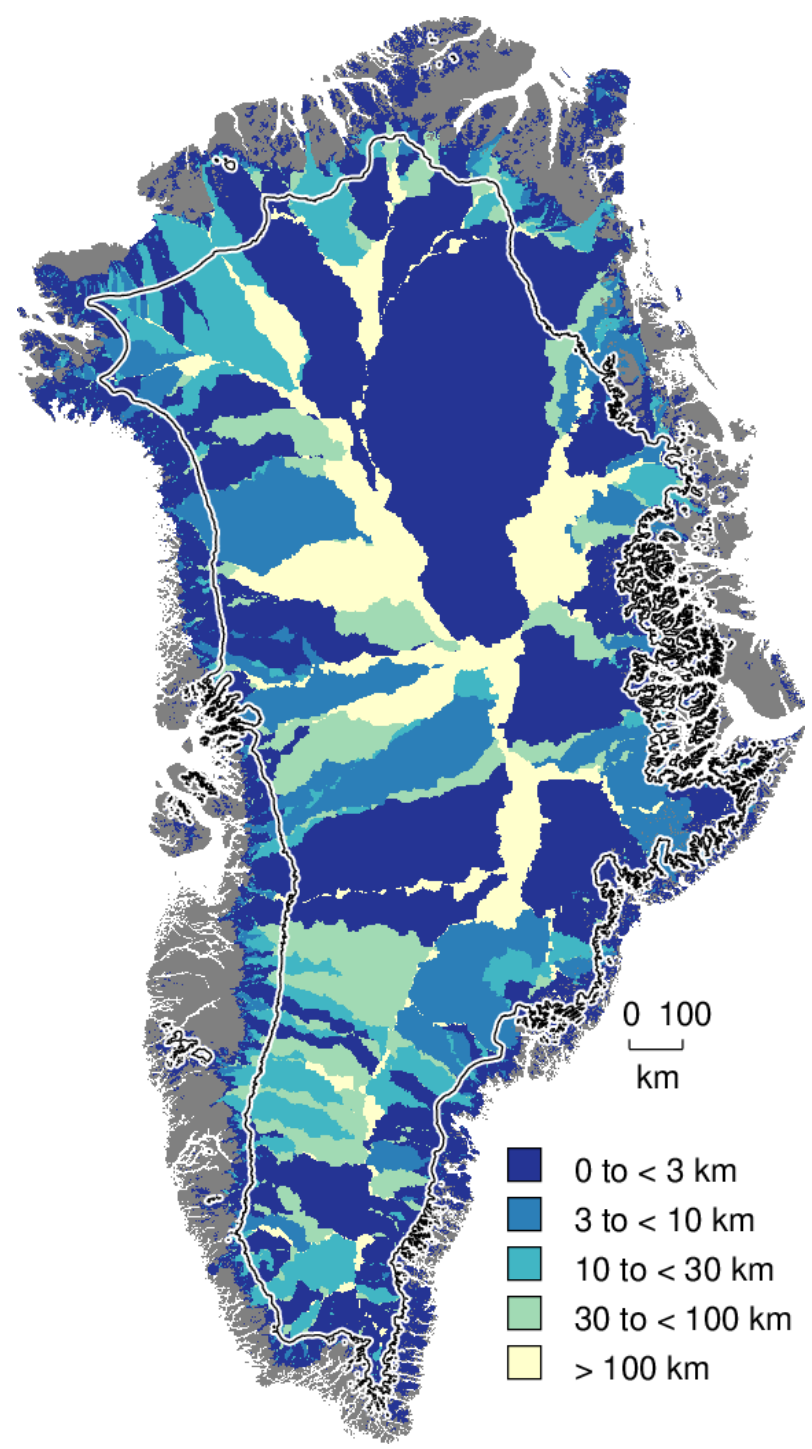

Figure 2. Basin changes with changing $k$. Map of Greenland showing maximum of all possible distances among outlet cell locations for all upstream cells, based on three effective basal pressure regimes $(k \in[0.8,0.9,1.0]$, Eq. 2$)$. Contour line shows $1500 \mathrm{~m}$ elevation contour - most runoff occurs below this elevation.

lines mark the mean, 0.05 , and 0.95 quantile of the ratio between the RCM and the observations. A value of $1\left(\right.$ or $\left.10^{\circ}\right)$ is agreement between observations and the RCM, and a value of 2 or 0.5 is a factor of 2 or a $+100 /-50 \%$ disagreement. The horizontal split marks the bottom one-third and top twothirds quantiles of discharge.

\section{Product evaluation and assessment}

Results of this work include (1) ice-margin-terminating streams, outlets, and basins; (2) coast-terminating streams, outlets, and basins; (3) discharge at the ice marginal outlets from ice runoff; and (4) discharge at the coastal out- lets from land runoff. Discharge products are provided from both the MAR and RACMO RCMs. We note that our subglacial streams represent where the model routes the water and do not indicate actual streams, unlike the land streams that do appear near actual streams when compared to satellite imagery. Even so, these streams routed using simple subglacial theory show remarkable alignment with ice surface streams and lakes visible in satellite imagery. This may support the theory that basal topography exerts a strong control on supraglacial hydrology (Lampkin and VanderBerg, 2011; Sergienko, 2013; Crozier et al., 2018), or may indicate a poorly represented and smooth bed in BedMachine, and therefore Eq. (2) is effectively applying surface routing in these locations.

Of the $361950 \mathrm{~km}^{2}$ of basin land cells, the RCMs cover $339749 \mathrm{~km}^{2}(\sim 94 \%)$ with their land grid cells, and $22201 \mathrm{~km}^{2}(\sim 6 \%)$ of basin grid cells are filled in with our coverage algorithm (Sect. 3.3; the RCMs have these as ice or ocean). A total of $51532 \mathrm{~km}^{2}$ of RCM land is discarded because the basins classify part or all of these cells as ice or ocean. Of the $1781816 \mathrm{~km}^{2}$ of basin ice cells, the RCMs cover $1760912 \mathrm{~km}^{2}(\sim 99 \%)$ with their ice cells, and $20904 \mathrm{~km}^{2}(\sim 1 \%)$ of basin grid cells are filled in (the RCMs have these as land or ocean). A total of $21793 \mathrm{~km}^{2}$ of RCM ice is discarded, because the basins classify part or all of these cells as land or ice (table and data available at https://github.com/mankoff/freshwater, Mankoff, 2020b).

Our coverage correction (Sect. 3.3) adjusts RCM ice runoff values by $\sim 3 \%$. Discarding RCM ice runoff that does not match the underlying mask ice cells results in a $5 \%$ reduction in discharge. However, applying our coverage algorithm to adjust RCM inputs for regions where basins have ice but the RCMs do not results in an $8 \%$ increase from the reduced discharge (net gain of $\sim 3 \%$ ). A similar adjustment occurs for RCM land runoff.

\subsection{Comparison with previous similar work}

Our static products - streams, outlets, and basins - have been previously estimated. Lewis and Smith (2009) identified 293 distinct hydrologic ice basins and provided a data set of ice basins and ice margin outlets. Our work, a decade later, has $\sim 2$ orders of magnitude more basins and outlets because of the higher resolution of the input data and includes additional data. We provide ice basins, ice margin outlets, ice streams with metadata, land basins, coastal outlets, and land streams with metadata. Lewis and Smith (2009) generated basins from a $5 \mathrm{~km}$ DEM, compared to the $100 \mathrm{~m}$ DEM used here. Routing with a $5 \mathrm{~km}$ DEM that does not capture smallscale topography is likely to cause some basins and outlets to drain into an incorrect fjord - we find that some land basins delineated with even the $150 \mathrm{~m}$ BedMachine land surface may drain into the incorrect fjord, but we did not find similar errors with the $100 \mathrm{~m}$ ArcticDEM product used in this work. 

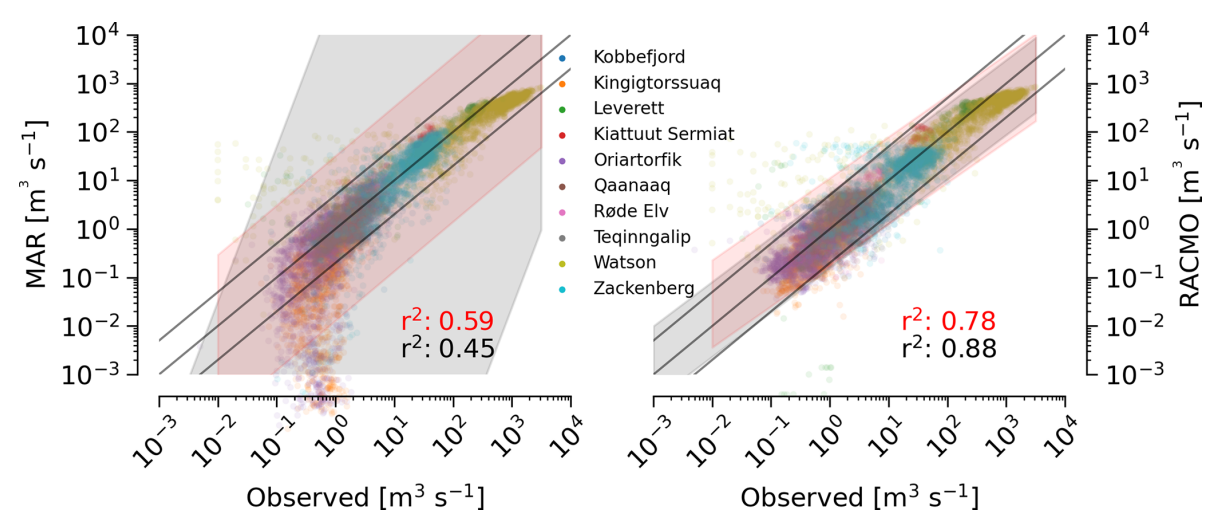

Figure 3. Bulk observation vs. RCM scatter plots. Daily runoff vs. observations for 10 outlets and a total of $15778 \mathrm{~d}$. Solid lines show $1: 1$ (center), $1: 5$ (upper), and 5:1 (lower). Grey band shows 5\% to $95 \%$ prediction interval. Red band shows $5 \%$ to $95 \%$ prediction interval when removing the GEM stations near Nuuk (Table 1) that have small glaciers not included in the RCMs (5341 d remain).

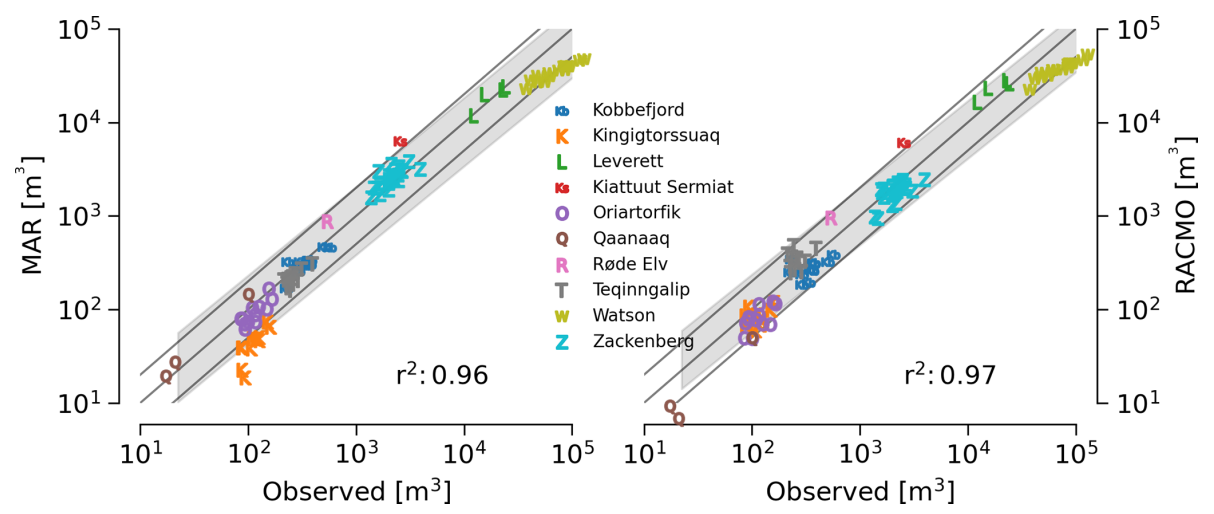

Figure 4. Bulk observation vs. RCM scatter plots. Similar to Fig. 3, except here showing annual sum of observed runoff - all days within each year when observations exist are summed. Days without observation are excluded from this comparison. Solid lines show $1: 1$ (center), $1: 2$ (upper), and $2: 1$ (lower). Grey band shows $5 \%$ to $95 \%$ prediction interval.

Our time series product (discharge) also has existing similar products. The most recent of these is from Bamber et al. (2018), who provide a data product at lower spatial resolution $(5 \mathrm{~km})$, lower temporal resolution (monthly), and only coastal discharge, not coastal basins, ice basins, or ice margin outlets and discharge. However, Bamber et al. (2018) surpasses our product in that spatial coverage includes a larger portion of the Arctic including Iceland, Svalbard, and Arctic Canada. Furthermore, by providing data at $5 \mathrm{~km}$ spatial and monthly temporal resolution, Bamber et al. (2018) implements the main strategy suggested here to increase the signalto-noise ratio of the data - averaging discharge in space or time (see Sect. 4.3.5).

We show both the geospatial and temporal differences between this product and Bamber et al. (2018) for an example location - Disko Island (Fig. 6). Spatially our product allows assessment of discharge at interior locations, necessary when comparing with observations that are not at the coast (for example, the Leverett Glacier observations, Fig. 9). Temporally, the MAR and RACMO runoff summed over all of Disko Island and to monthly resolution is similar to the monthly Disko Island discharge of Bamber et al. (2018), but the daily resolution shows increased variability and individual discharge events (from warm days or rain) not seen in the monthly view.

A similar GIS workflow was presented by Pitcher et al. (2016) only focusing on the discharge uncertainty from basal routing assumptions (the $k$ parameter in Eq. 2). We find these differences to be smaller than the differences between RCMs or between RCM and observations (see Sect. 4.3).

\subsection{Validation against observations}

Here we compare our results to all publicly accessible observations we could find or those willing to become open and publicly accessible as part of this work (Table 1).

This validation compares observations with discharge at stream gauges derived from RCM runoff estimates, much of it coming from far inland on the ice sheet. Disagreement is expected and does not indicate any specific issues in 


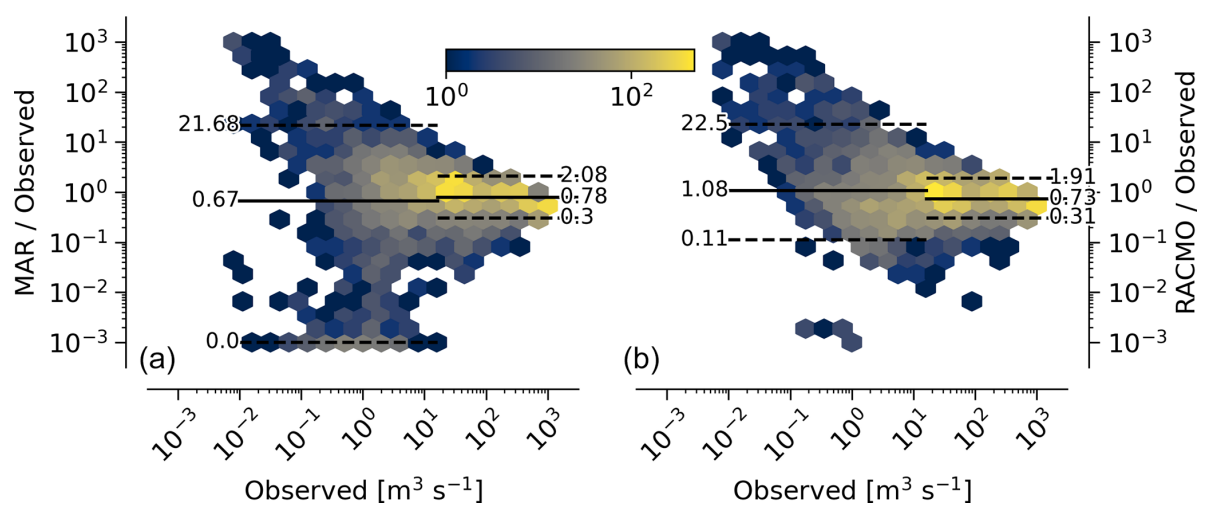

Figure 5. Modified Tukey plot for non-Nuuk observations. Observation vs. ratio of RCM to observations for MAR (a) and RACMO (b), discussed in Sect. 4.2.1. Number of samples at a location is represented by color. The horizontal solid line shows the mean, dashed lines show the $5 \%$ to $95 \%$ quantile range, and the horizontal split denotes the bottom one-third and top two-thirds quantiles of observed discharge. The four near-Nuuk GEM basins which have glaciers not included in the RCM domain are excluded.

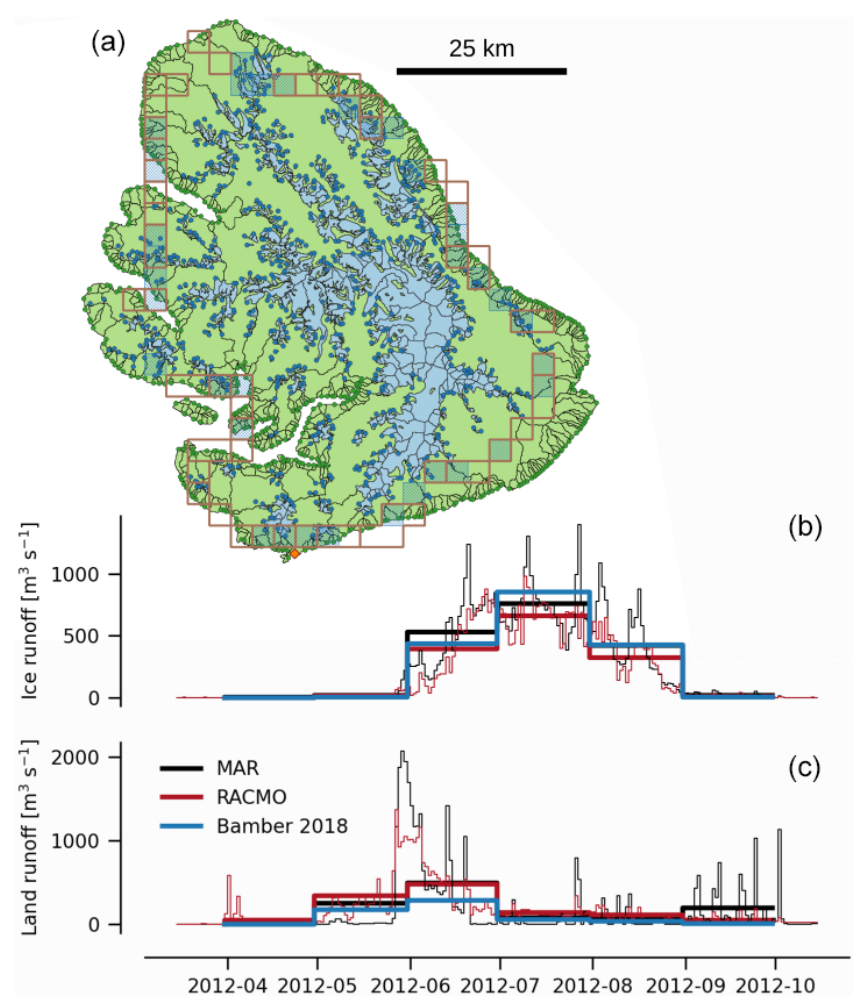

Figure 6. Disko Island comparison between this product and Bamber et al. (2018). Light green are land basins with dark green outlet dots. Light blue are ice basins with dark blue outlet dots. Brown and hatched blue $5 \mathrm{~km}^{2}$ cells are the land and ice runoff locations, respectively, from Bamber et al. (2018). Bottom graphs show ice (b) and land (c) runoff for the 2012 runoff calendar year. the RCMs but is instead likely due to our routing algorithm (Sect. 3.3).

Below we discuss first the validation for all discharge estimates together and then the individual outlets. For the individual outlets we begin by focusing on the problematic results in order of severity - Watson River (Figs. 7 and 8), Leverett Glacier (Fig. 9), and Kiattuut Sermiat (Fig. 10) - and show that for two of these three, simple solutions are available, although manual intervention is needed to detect the issue and then adjust results.

\subsubsection{Bulk validation}

A comparison of every day of observational data with discharge $>0$ (15778d) and the two RCMs (Fig. 3) shows good agreement with $r^{2}$ of 0.45 and 0.88 for discharge derived from MAR and RACMO runoff respectively (hereafter "MAR" and "RACMO"). This comparison covers more than 4 orders of magnitude of modeled and observed discharge. The RACMO vs. observed discharge is within a factor of 5 (e.g., plus or minus half an order of magnitude), although both RCMs report only $\sim 50 \%$ of the observed discharge for the largest volumes at the Watson River outlet (Fig. 7). The reason for the disagreement at the Watson River outlet is discussed in detail in Sect. 4.2.2.

The four near-Nuuk GEM basins (Table 1, Sect. 4.2.5) have ice basins but either no or limited coverage in the RCMs. When excluding these basins from the comparison the $r^{2}$ agreement changes to 0.59 and 0.78 for MAR and RACMO respectively, and the $5 \%$ to $95 \%$ prediction interval is significantly smaller for MAR (red band in Fig. 3). The largest disagreements throughout this work come from these small basins with no RCM coverage. These disagreements are therefore indicative of differences between the land/ice classification mask used by the RCMs compared with the basin masks used here and not necessarily an insufficient 

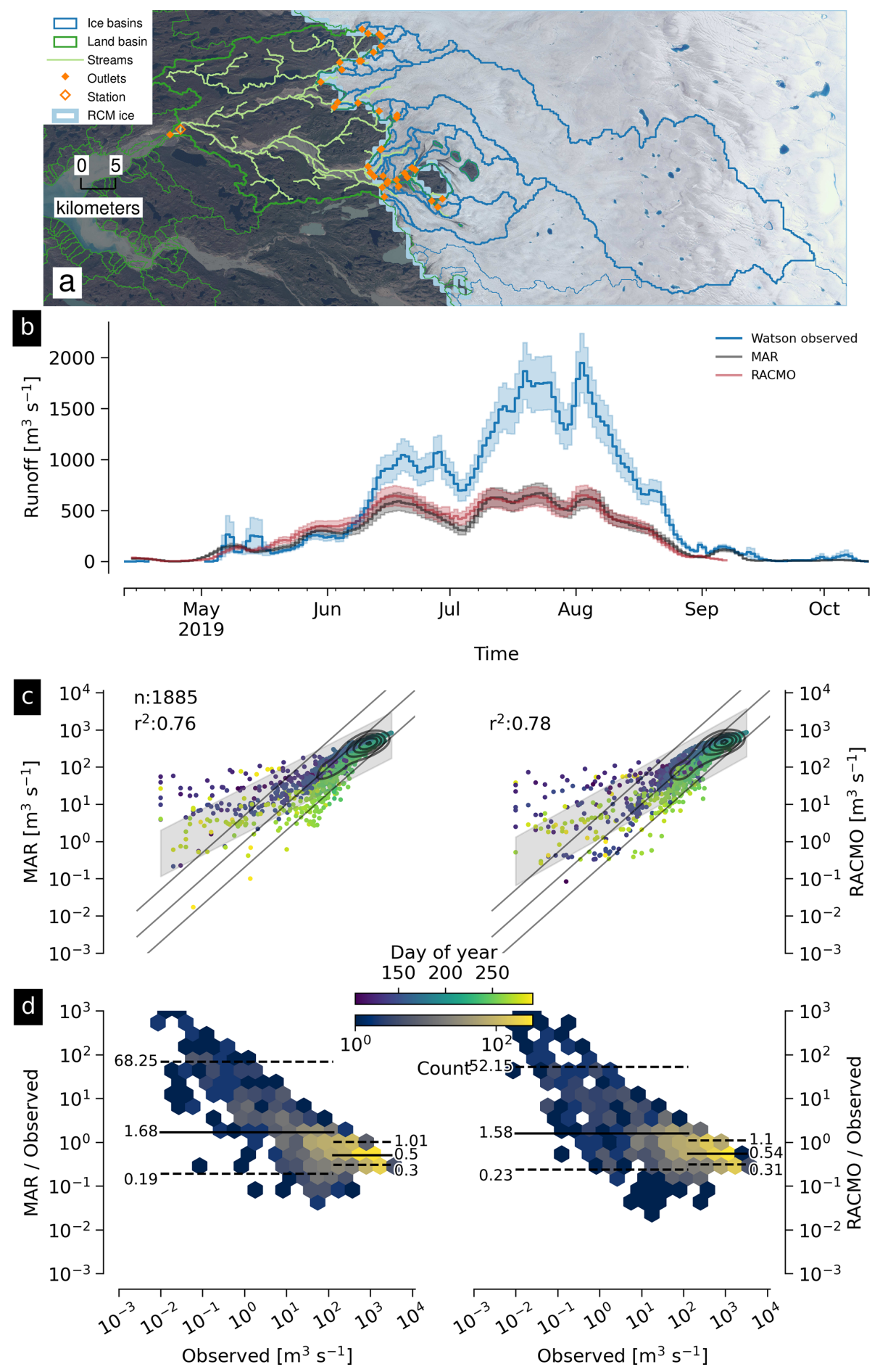

Figure 7. Graphical summary of Watson River outlet, basin, and discharge (W in Fig. 1). See Sect. 3.4 for a general overview of graphical elements and Sect. 4.2.2 for discussion of the Watson River basin. Basemap from Howat et al. (2014) and Howat (2017a).

ability of the models to simulate melting (near-surface) climate conditions.

Figure 4 shows a similar view as Fig. 3, but here each observational data set and associated daily discharge is summed by year for the days in that year that observations exist (hence units $\mathrm{m}^{3}$ and not $\mathrm{m}^{3} \mathrm{yr}^{-1}$; for example four " $\mathrm{L}$ " means there are four calendar years with some observations at the Leverett outlet). Here it is more clear that the Watson River outlet (Sect. 4.2.2) reports $\sim 50 \%$ of the observed discharge, the Kiattuut Sermiat outlet (Sect. 4.2.4) overestimates discharge, 
(a)
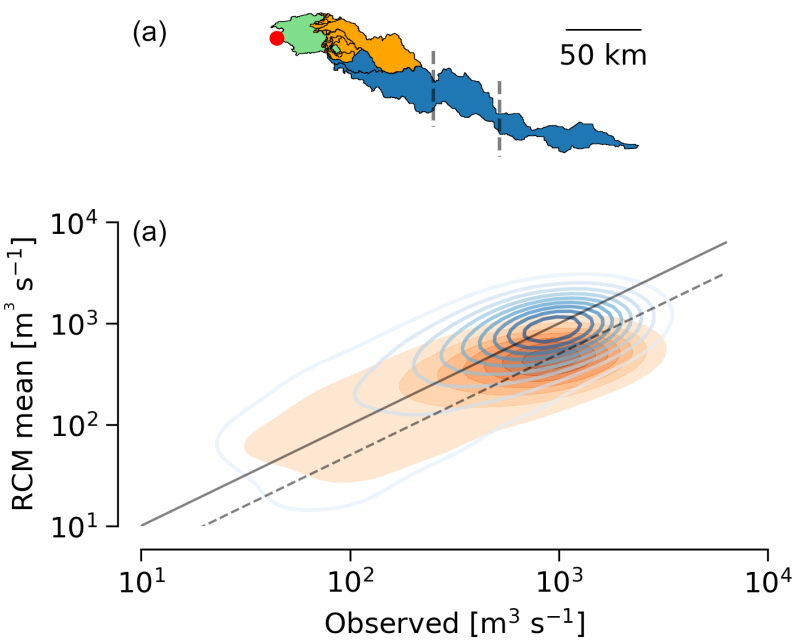

Figure 8. Watson River and manually adjusted basin area. (a) Map view showing land and ice basin from this work - green and orange, respectively, are the same as the region shown in Fig. 7, and two additional basins to the south are shown in blue. Vertical dashed lines denote approximate location of 1500 and 1850 m elevation. (b) Kernel density estimate (concentration of points) comparing observed vs. average of RACMO and MAR RCM runoff for the default land and ice basin (orange; filled) and with the additional southern basins (blue; lines). Solid and dashed lines are $1: 1$ and $2: 1$ (respectively) observed-to-RCM ratios.

and the remainder fall within the factor-of-2 lines, except for low discharge at Kingigtorssuaq in the MAR RCM where the RCMs do not cover that small glacier (Sect. 4.2.5).

Because discharge spans a wide range ( $\sim 4$ orders of magnitude, Fig. 3), a high correlation ( $r^{2}$ of 0.88 , Fig. 3) may be due primarily to the range, which is larger than the error (Altman and Bland, 1983; Martin Bland and Altman, 1986). Figure 5 compensates for this by comparing the observations with the ratio of the RCM to the observations. This graphic again excludes the four near-Nuuk GEM basins. From Fig. 5, the top two-thirds of observed discharge has modeled discharge underestimated by a factor of 0.78 (MAR) and 0.73 (RACMO), as well as $5 \%$ to $95 \%$ quantile of 0.30 to 2.08. The top two-thirds of observed discharge spans $\sim 2$ orders of magnitude (width of horizontal lines, from $\sim 10^{1}$ to $\sim 10^{3} \mathrm{~m}^{3} \mathrm{~s}^{-1}$ ). The ratio of the RCMs to these observations for the top two-thirds has a $5 \%$ to $95 \%$ quantile range of $\sim 1$ order of magnitude (distance between horizontal lines, from $\log _{10} 0.3$ to $\log _{10} 2.08=0.84$ ). The $5 \%$ to $95 \%$ quantile range of the ratio between the RCMs and the observations is therefore half the range of the observations. Put differently, days with high observed discharge may have modeled discharge within \pm 0.5 order of magnitude, or plus or minus a factor of 5 , or $+500 /-80 \%$. The modeled discharge is not likely to move farther than this from the observations, and high discharge remains high.
The bottom third of discharge is where the largest disagreement occurs. The mean model values are near the observed - the ratio of RCM to observed discharge is scaled by 0.67 for MAR $(\sim 33 \%$ low $)$ and 1.08 for RACMO $(\sim 8 \%$ high), but the $5 \%$ to $95 \%$ quantile range of the ratio between $\mathrm{RCM}$ and observations is large. Although large uncertainties for low discharge may not seem to matter for some uses (e.g., estimates of total discharge from Greenland, which is dominated by the largest quantities of discharge), it may matter for other uses. The bottom one-third quantile of observed discharge spans 3 orders of magnitude $\left(10^{-2}\right.$ to $\left.\sim 10^{1}\right)$, but the uncertainty of the RCM-to-observation ratio spans $\sim 4$ and $\sim 2$ orders of magnitude for MAR and RACMO respectively $\left(\sim 10^{-3}\right.$ to $\sim 2.2 \times 10^{1} \mathrm{MAR} ; \sim 10^{-1}$ to $\left.2.2 \times 10^{1} \mathrm{RACMO}\right)$.

\subsubsection{Watson River}

The Watson River discharge basin area is $1882 \mathrm{~km}^{2}$, of which $521 \mathrm{~km}^{2}(28 \%)$ is land and $1361 \mathrm{~km}^{2}(72 \%)$ is ice (Fig. 7a). The partial (last calendar year) discharge time series shows MAR and RACMO agree well with each other but have a maximum of $500 \mathrm{~m}^{3} \mathrm{~s}^{-1}$, while observations are up to $4 \times$ more (Fig. 7b). Low discharge (both early and late season) is overestimated, and high discharge is underestimated, approximately equal for both RCMs (Fig. 7c). The low discharge overestimate ranges from a mean multiple of 1.68 (MAR) and 1.57 (RACMO) to a $+95 \%$ quantile ratio of $\sim 70$ (MAR) and $\sim 52$ (RACMO). The high-discharge underestimate has a mean multiple of $\sim 0.5$ for both MAR and RACMO and a 5 to 95 quantile range of between 0.23 to 1.09 .

The Watson River discharge presented here is approximately half of the van As et al. (2018) discharge for high discharge. The large underestimate for high discharge may be due to either errors in the basin delineation used in this study, errors in the stage-discharge relationship used by van As et al. (2018), errors in the RCM runoff estimates, or a combination of the above three. All three of these error sources increase with high discharge (and associated melt): basin delineation becomes less certain with inland distance from the ice sheet margin. The river stage-discharge conversion becomes less certain at high stage levels. Runoff calculations become less certain from a snow surface than an ice surface because of, e.g., snow density, subsurface refreezing, and surface darkening.

The complexity of estimating the area of the Watson River catchment is described by Monteban et al. (2020), who note that previous studies have used values ranging from $6131 \mathrm{~km}^{2}$ (Mernild et al., 2010b) to $12547 \mathrm{~km}^{2}$ (van As et al., 2012). Our basin is smaller than the basin used in van As et al. (2018) and similar to Mernild et al. (2018), who attributed the difference between their modeled outflow and observations from van As et al. (2017) to their decision to use surface rather than subglacial routing and applied a correction term. We find that our basin does not include a separate basin to the south that is part of the Watson River ice 

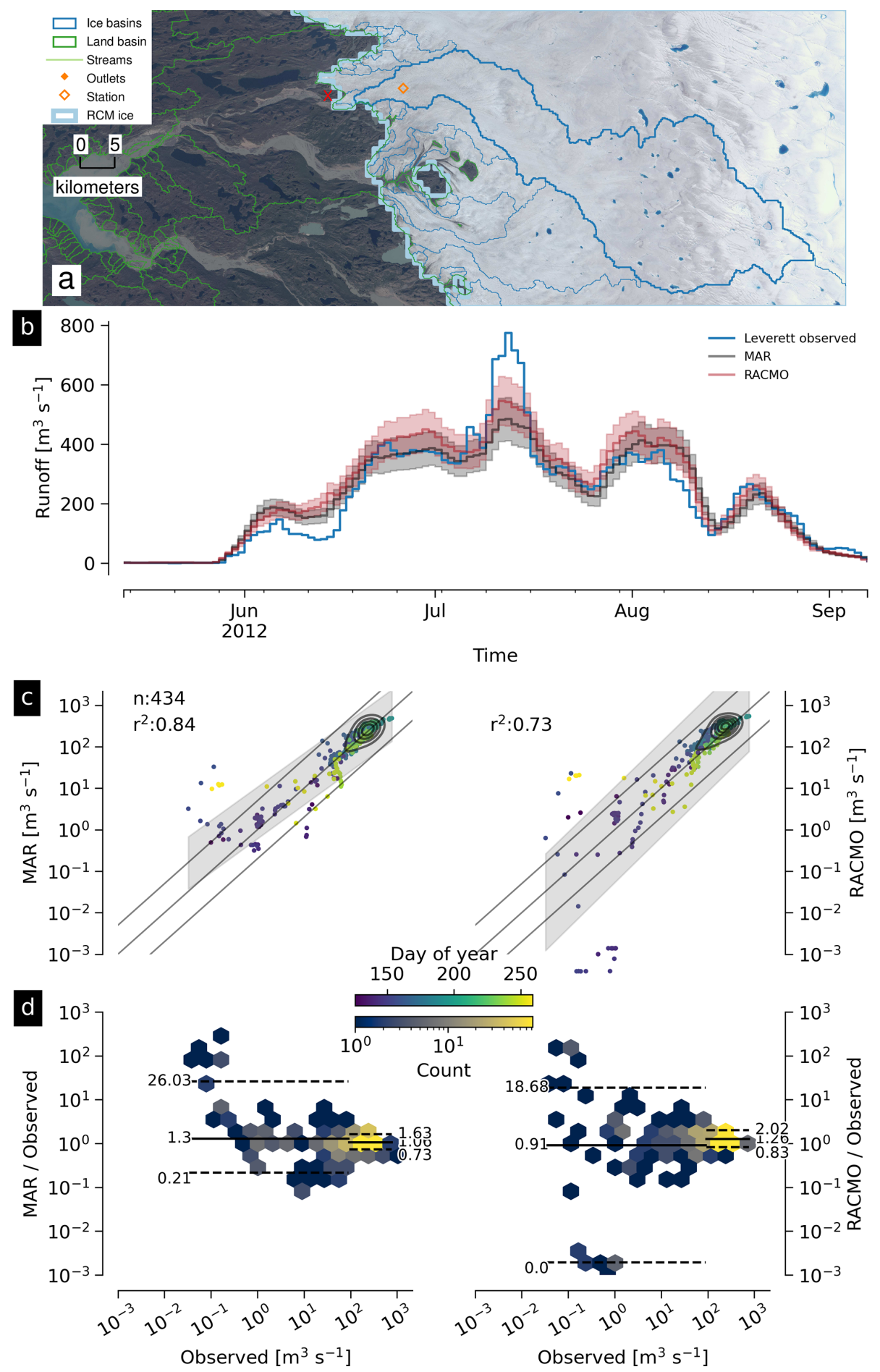

Figure 9. Graphical summary of Leverett Glacier outlet, basin, and discharge (L in Fig. 1). Red X in panel (a) marks approximate observation location, but adjusted here to an orange diamond within the ice basin. See Sect. 3.4 for a general overview of graphical elements and Sect. 4.2.3 for discussion of the Leverett Glacier basin. Basemap from Howat et al. (2014) and Howat (2017a). 

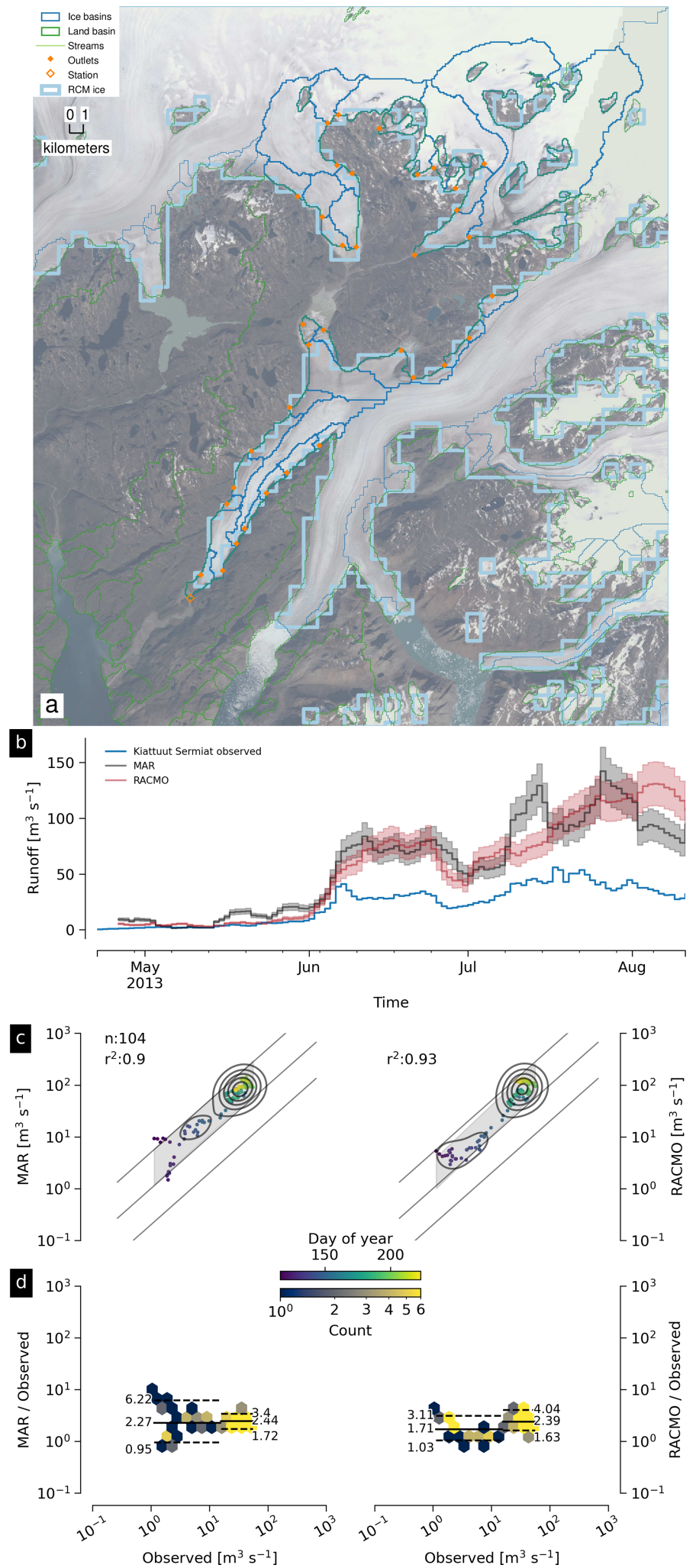

Figure 10. Graphical summary of Kiattuut Sermiat outlet, basin, and discharge (Ks in Fig. 1). See Sect. 3.4 for a general overview of graphical elements and Sect. 4.2.4 for discussion of the Kiattuut Sermiat basin. Basemap from Howat et al. (2014) and Howat (2017a). 
basin in van As et al. (2018) (from Lindbäck et al., 2015 and Lindbäck et al., 2014). We are able to recreate the van As et al. (2018) basin but only when using the Lindbäck et al. (2014) bed and the Bamber et al. (2013) surface. When using any other combination of bed DEM, surface DEM, or $k$ values, we are unable to match the Lindbäck et al. (2015) basin. Instead all our basins resemble the basin shown in Fig. 7. To solve this, we manually select two large ice basins to the south of the Watson River ice basin. Modeled and observed discharge agree after including these two basins (Fig. 8), suggesting basin delineation, not stage-discharge or RCM runoff, is the primary cause for this disagreement. Furthermore, it is the additional width at lower elevation from the larger basin, not the increased inland high-elevation area, that likely contributes the runoff needed to match the observations, because $85 \%$ of all surface runoff occurs below $1350 \mathrm{~m}$ and almost all below 1850 (van As et al., 2017).

At the Watson River outlet, there is no reason to suspect this product underestimates observed discharge by $50 \%$. The observations are needed to highlight the disagreement. Once this disagreement is apparent, it is also not clear what to do to reduce the disagreement without the previous efforts by Lindbäck et al. (2015) and Lindbäck et al. (2014). Basin delineation is discussed in more detail in the uncertainty section (Sect. 4.3.2). The other two problematic areas highlighted above (Sect. 4.2) can be detected and improved without observational support.

\subsubsection{Leverett Glacier}

The Leverett Glacier basin area is $1361 \mathrm{~km}^{2}$ and $100 \%$ ice (Fig. 9a). The partial (last calendar year) discharge time series shows MAR and RACMO agree well with each other and with the observations (Fig. 9b), with no seasonal dependence (Fig. 9c). The $5 \%$ to $95 \%$ prediction interval for MAR is generally within the $1: 5$ and $5: 1$ bands, with a larger spread for RACMO (Fig. 9c). High model discharge is $3 \%$ higher than observed (MAR) or $25 \%$ higher than observed (RACMO), and the 5 to 95 quantile range of the ratio is between 0.73 and 1.62 (MAR) and 0.83 and 2.02 (RACMO). Low model discharge is also centered near the observations, but as always larger errors exist for low discharge (Fig. 9d).

This basin is problematic because the basin feeding the outlet is small $\left(<5 \mathrm{~km}^{2}\right)$, but even without the observational record satellite imagery shows a large river discharging from the ice sheet here. Meanwhile, a large $\left(100 \mathrm{~s}\right.$ of $\left.\mathrm{km}^{2}\right)$ ice basin does discharge just a few $100 \mathrm{~m}$ away but not upstream of this gauge location. We therefore adjust the gauge location onto the ice (equivalent to selecting a different outlet) so that our database access software selects what appears to be the correct basin given the size of the stream in the satellite imagery (Fig. 9).

The plots shown here use the adjusted gauge location and modeled discharge appears to match the observed discharge. When plotting (not shown) the modeled discharge for the outlet just upstream of the true gauge location, results are clearly incorrect. This issue - small basins at the margin and incorrect outlet location - is persistent throughout this product and discussed in more detail in Sect. 4.3.2.

The Leverett Glacier basin is a subset of the Watson River outlet basin (Sect. 4.2.2). The strong agreement here supports our claim that the Watson River disagreement is not from the RCM runoff or the stage-discharge relationship but more likely due to basin area. The correct Watson River basin should include some basins outside of the Leverett Glacier basin that still drain to the Watson River outlet gauge location.

\subsubsection{Kiattuut Sermiat}

The Kiattuut Sermiat discharge basin area is $693 \mathrm{~km}^{2}$, of which $391 \mathrm{~km}^{2}(56 \%)$ is land and $302 \mathrm{~km}^{2}(44 \%)$ is ice. The basin area is incorrectly large because the land basin reported and shown includes the entire basin that contains the discharge point, of which some is downstream (Fig. 10a). However, only $\sim 25 \%$ of runoff comes from the land, and only a small portion of the land basin is downstream of the gauge location, so this is not enough to explain the discharge vs. observation disagreement. The partial (last calendar year) discharge time series shows MAR and RACMO agree well with each other but are significantly higher than the observations (Fig. 10b). Both low and high discharge are overestimated, but the $5 \%$ to $95 \%$ quantile range of the ratio are within a factor of 5 (Fig. 10c), with a mean ratio between 1.71 (RACMO bottom one-third of discharge) to 2.44 (MAR high two-thirds discharge)

The Kiattuut Sermiat gauge is in a problematic location in terms of determining the actual (nontheoretical) upstream contributing area. Similar to the Leverett Glacier gauge location, the issues here can be estimated independent of observational data. Specifically, it is not clear if this stream includes water from the larger glacier to the east and east-northeast that feeds this glacier (Fig. 10a) - in our delineation it does not. Furthermore, several glaciers to the north-northwest and detached from the glacier near the stream gauge appear to drain into a lake that then drains under the glacier and then to the stream gauge. This latter issue is observable in any cloud-free satellite imagery and does not need the basin delineations provided here to highlight the complexities of this field site. Nonetheless, RCM discharge estimates are only slightly more than double the observations.

The Kiattuut Sermiat gauge location may have been selected in part due to its accessibility - it is walking distance from the Narsarsuaq Airport. The data may also suit their intended purpose well and there are likely many results that can be derived independent of the area or location of the upstream source water. However, if the location or area of the upstream contributions is important, then gauge location should balance ease of access and maintenance with the ease 
with which the data can be interpreted in the broader environment.

\subsubsection{GEM observations near Nuuk}

Four Greenland Ecosystem Monitoring (GEM) program stream gauges are located near Nuuk, with similar basin properties. All are small $\left(7.56\right.$ to $\left.37.52 \mathrm{~km}^{2}\right)$ and $10 \%$ to $25 \%$ ice in the basin mask, but two of the four (Kingigtorssuaq, Fig. 11; and Oriartorfik, Fig. 12) contain small glaciers contributing to observed discharge but no RCM ice cells cover those glaciers, and the remaining two (Teqinngalip, Fig. 13; and Kobbefjord, Fig. 14) have several small glaciers, but only one per basin has RCM ice coverage.

All four of these basins show some weak agreement. The maximum $r^{2}$ is 0.47 (Fig. 13c) and the minimum is 0.11 (Fig. 11c), but we note that the worst agreement comes from a basin with no glaciers in the RCM domain and that in all cases the mean high discharge agrees well, suggesting high discharge in these small basins with few small glaciers may be due to rain (captured in the RCMs) rather than warm days and melted ice.

\subsubsection{Remaining observations}

Three additional stream gauges remain: Røde Elv, Zackenberg, and Qaanaaq.

The Røde Elv basin is situated at the southern edge of Disko Island (Fig. 6). It has an area of $100 \mathrm{~km}^{2}$, of which $72 \mathrm{~km}^{2}$ is land and $28 \mathrm{~km}^{2}$ is ice (Fig. 15a). The partial (last calendar year) discharge time series shows MAR, RACMO, and the observations all in approximately the same range but with high variability (Fig. 15b). Of the few samples here ( $n=$ 98), most are within the factor-of-5 bands for MAR and a few more are outside the bands for RACMO (Fig. 15c). Mean discharge offset ranges from a ratio of 0.82 (RACMO low) to 1.85 (MAR low), with high-discharge estimates slightly closer to observations - a $48 \%$ and $77 \%$ overestimate for MAR and RACMO respectively (Fig. 15d).

The Zackenberg basin in NE Greenland has an area of $487 \mathrm{~km}^{2}$, of which $378 \mathrm{~km}^{2}(78 \%)$ is land and $109 \mathrm{~km}^{2}$ $(22 \%)$ is ice (Fig. 16a). The partial (last calendar year) discharge time series shows disagreements between MAR and RACMO that generally bound the observations (Fig. 16b). RACMO-derived discharge is consistently high for low discharge early in the year, but both discharge products fall mostly within the factor-of-5 bands (Fig. 16c). For high discharge, mean modeled discharge is $9 \%$ high (MAR) and $24 \%$ low (RACMO) and has a worst-case $5 \%$ to $95 \%$ quantile range low by a factor of 0.29 (Fig. 16d).

The Qaanaaq basin in NW Greenland has an area of $13.2 \mathrm{~km}^{2}$, of which $2.2 \mathrm{~km}^{2}(17 \%)$ is land and $11 \mathrm{~km}^{2}$ $(83 \%)$ is ice (Fig. 17a). The partial (last calendar year) discharge time series shows disagreements between MAR and RACMO that generally bound the observations (Fig. 17b). Of the few samples $(n=82)$, MAR preferentially overestimates and RACMO underestimates discharge, but both generally within a factor of 5 (Fig. 17c). The mean high-discharge ratio is 1.26 (MAR) and 0.4 (RACMO) from Fig. 17d.

\subsection{Uncertainty}

The volume of data generated here is such that manually examining all of it or editing it to remove artifacts or improve the data would be time and cost prohibitive. A similar warning is provided with the ArcticDEM data used here. However, any ArcticDEM issues interior to a basin do not impact results here that are aggregated by basin and reported at the outlet. ArcticDEM issues that cross basin boundaries should only impact a small part of the basin near the issue.

Uncertainty from RCM inputs and observations are considered external to this work, although they are still discussed (Sect. 4.3.3 and 4.3.4). In this work, we introduce one new source of uncertainty - the routing model, which generates both temporal (runoff delay) and spatial (basin delineation) uncertainty.

\subsubsection{Temporal uncertainty}

The RCMs include a time lag between when water melts in the model and when it leaves a grid cell. RACMO retention occurs only when there is firn cover (no retention when bare ice melts); MAR includes a time delay of up to $10 \mathrm{~d}$ that is primarily a function of surface slope (Zuo and Oerlemans, 1996; Yang et al., 2019). However, neither model includes a subglacial system. Properly addressing time delays with runoff requires addressing storage and release of water across a variety of timescales in a variety of media: firn (e.g., Munneke et al., 2014; Vandecrux et al., 2019), supraglacial streams and lakes (e.g., Zuo and Oerlemans, 1996; Smith et al., 2015; Yang et al., 2019), the subglacial system (e.g., Rennermalm et al., 2013), possibly terrestrial streams and lakes (e.g., van As et al., 2018), and a variety of other physical processes that are not within the scope of surface mass balance (SMB) modeling. Runoff delay can be implemented outside the RCMs (e.g., Liston and Mernild, 2012; Mernild et al., 2018), but for this version of the product we assume that, once an RCM classifies meltwater as runoff, it is instantly transported to the outlet. Actual lags between melt and discharge range from hours to years (Colgan et al., 2011; van As et al., 2017; Rennermalm et al., 2013; Livingston et al., 2013).

Data released here include no additional lag beyond the RCM lag, although a $7 \mathrm{~d}$ running mean (cf. van As et al., 2017) is included in all of the results presented here except Fig. 6, which shows monthly summed data, and Fig. 4, which shows yearly summed data. When increasing the signal to noise by summing by year (Fig. 4 vs. Fig. 3), model results more closely match observations. 


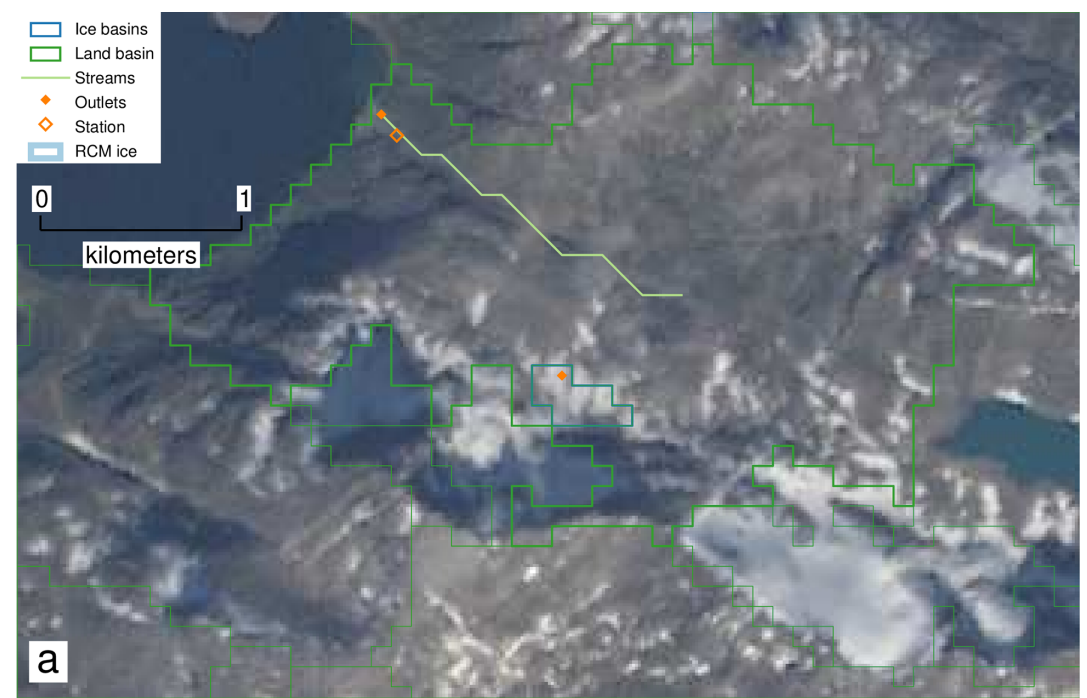

b
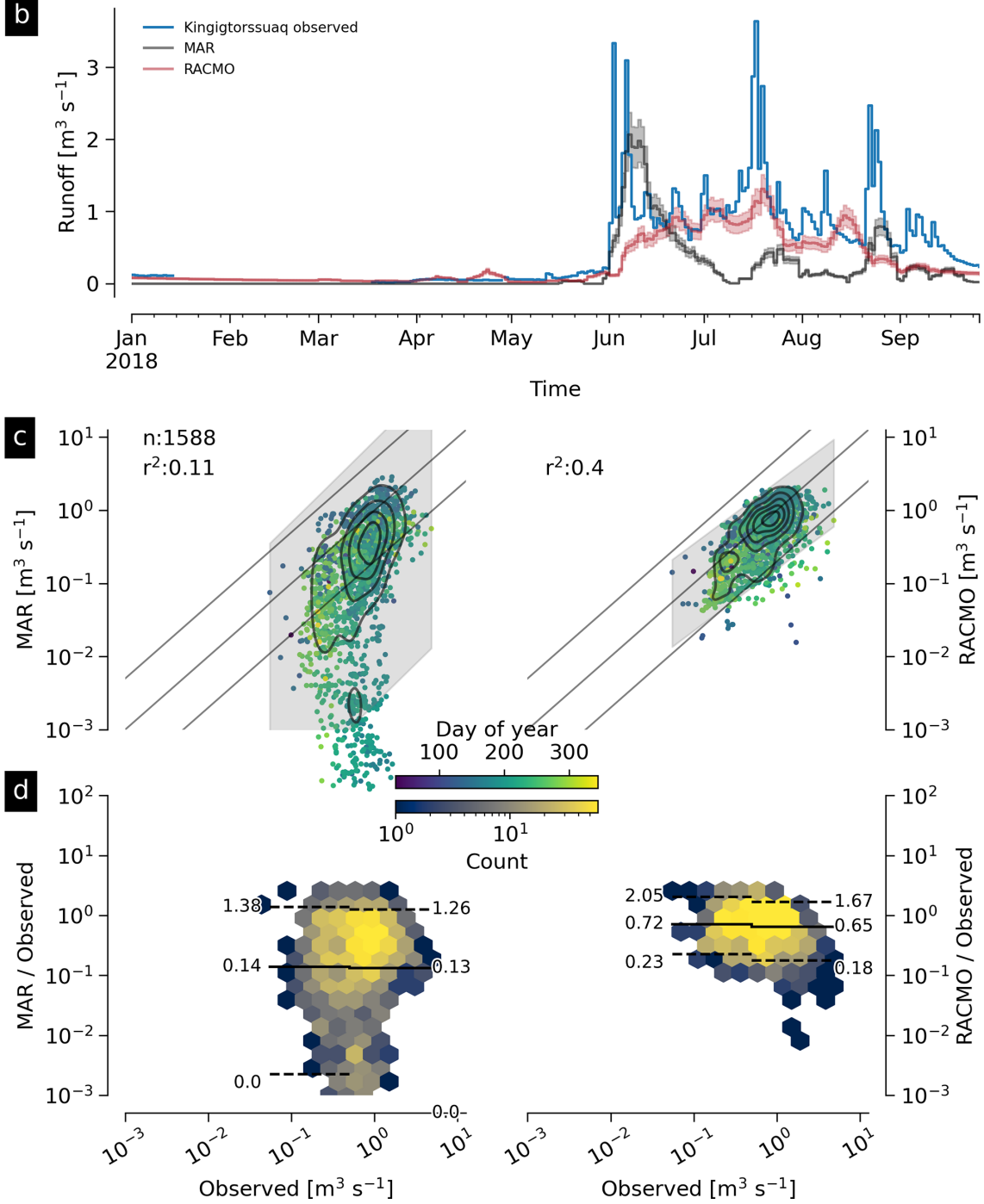

Figure 11. Graphical summary of Kingigtorssuaq outlet, basin, and discharge (K in Fig. 1). See Sect. 3.4 for a general overview of graphical elements and Sect. 4.2.5 for discussion of the Kingigtorssuaq basin. Basemap from Howat et al. (2014) and Howat (2017a). 


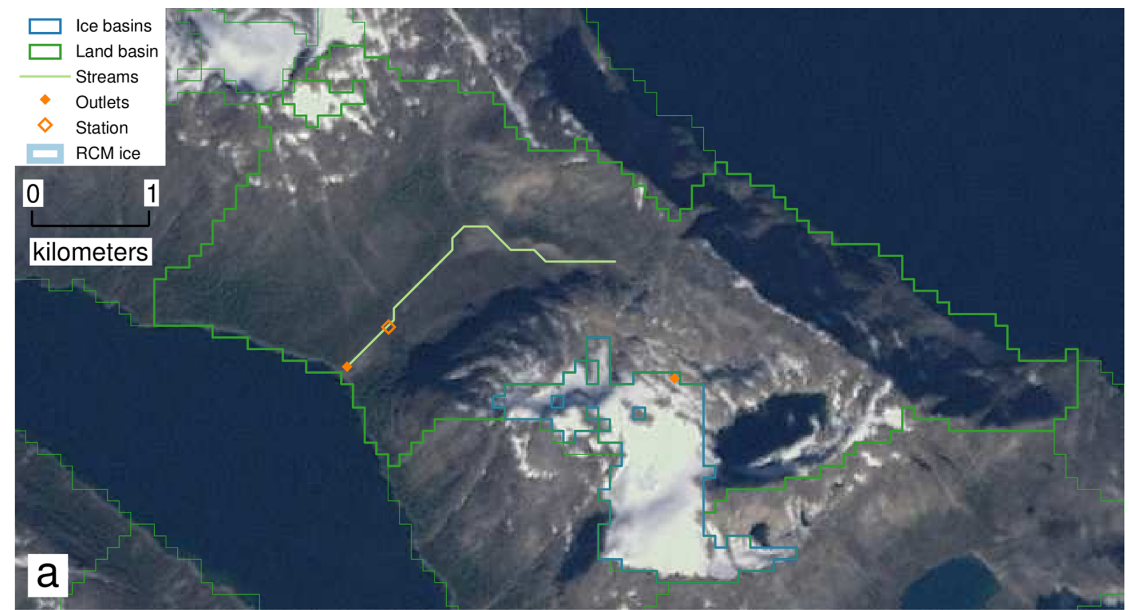

b
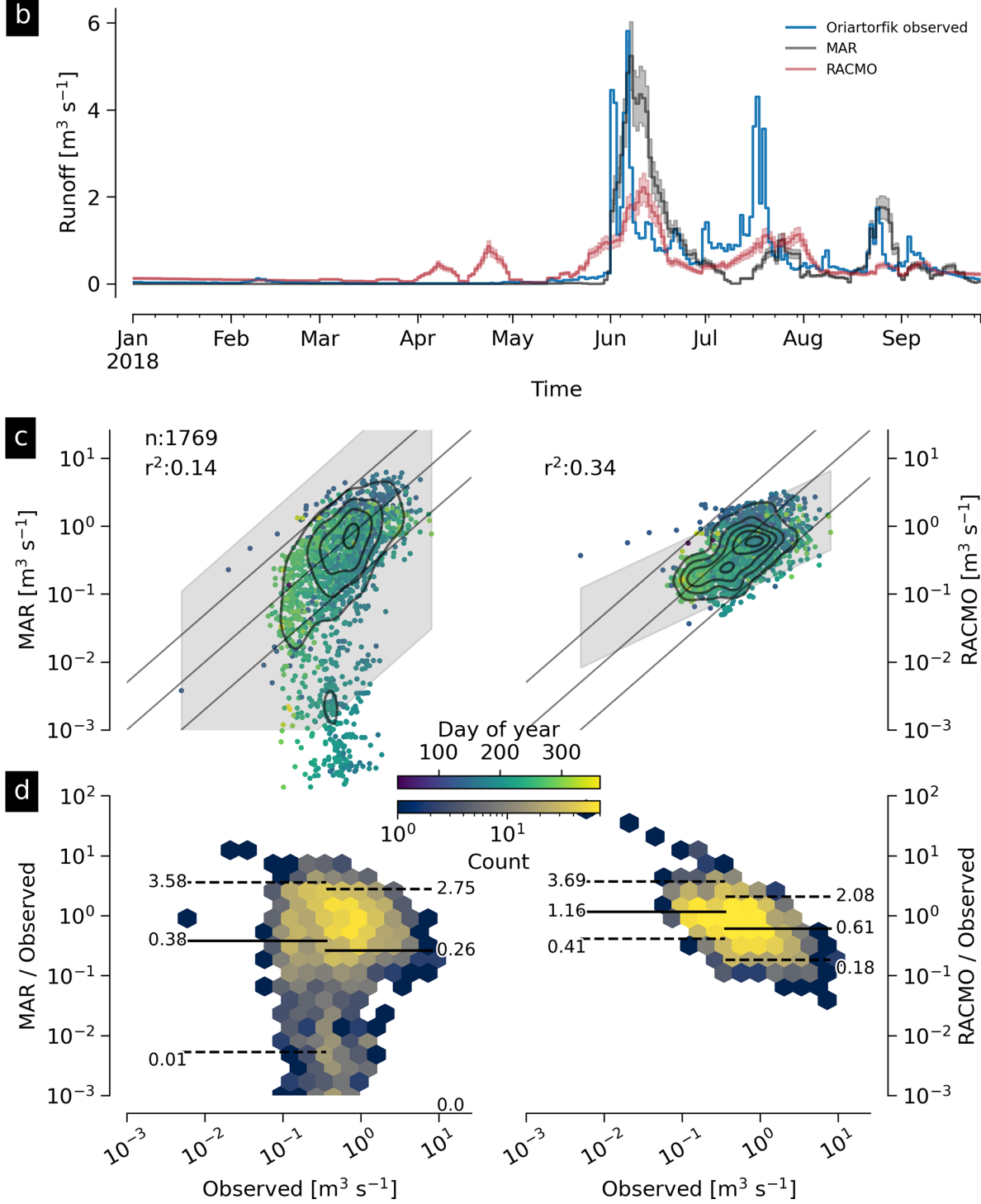

Figure 12. Graphical summary of Oriartorfik outlet, basin, and discharge (O in Fig. 1). See Sect. 3.4 for a general overview of graphical elements and Sect. 4.2.5 for discussion of the Oriartorfik basin. Basemap from Howat et al. (2014) and Howat (2017a). 

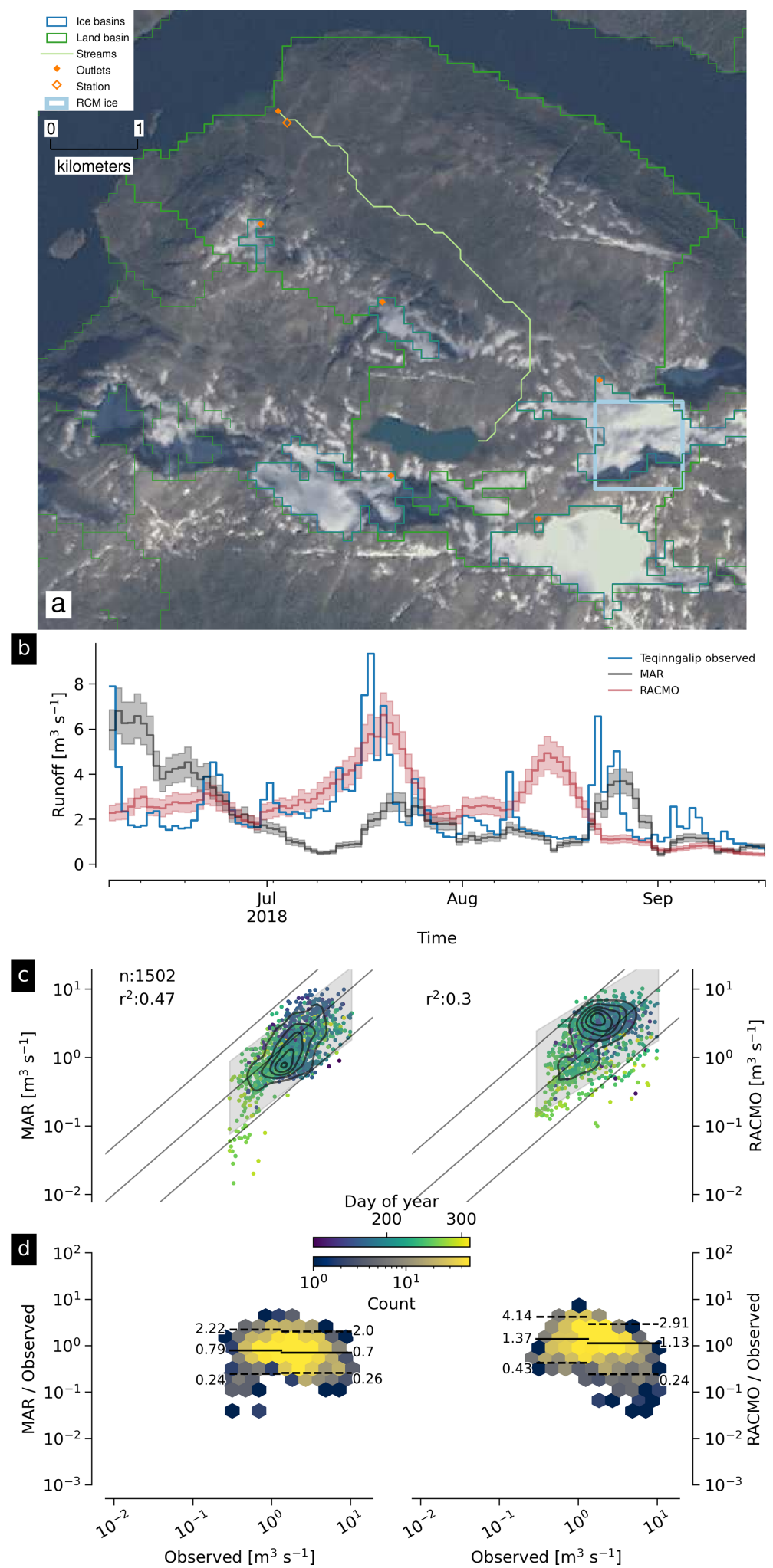

Figure 13. Graphical summary of Teqinngalip outlet, basin, and discharge (T in Fig. 1). See Sect. 3.4 for a general overview of graphical elements and Sect. 4.2.5 for discussion of the Teqinngalip basin. Basemap from Howat et al. (2014) and Howat (2017a). 

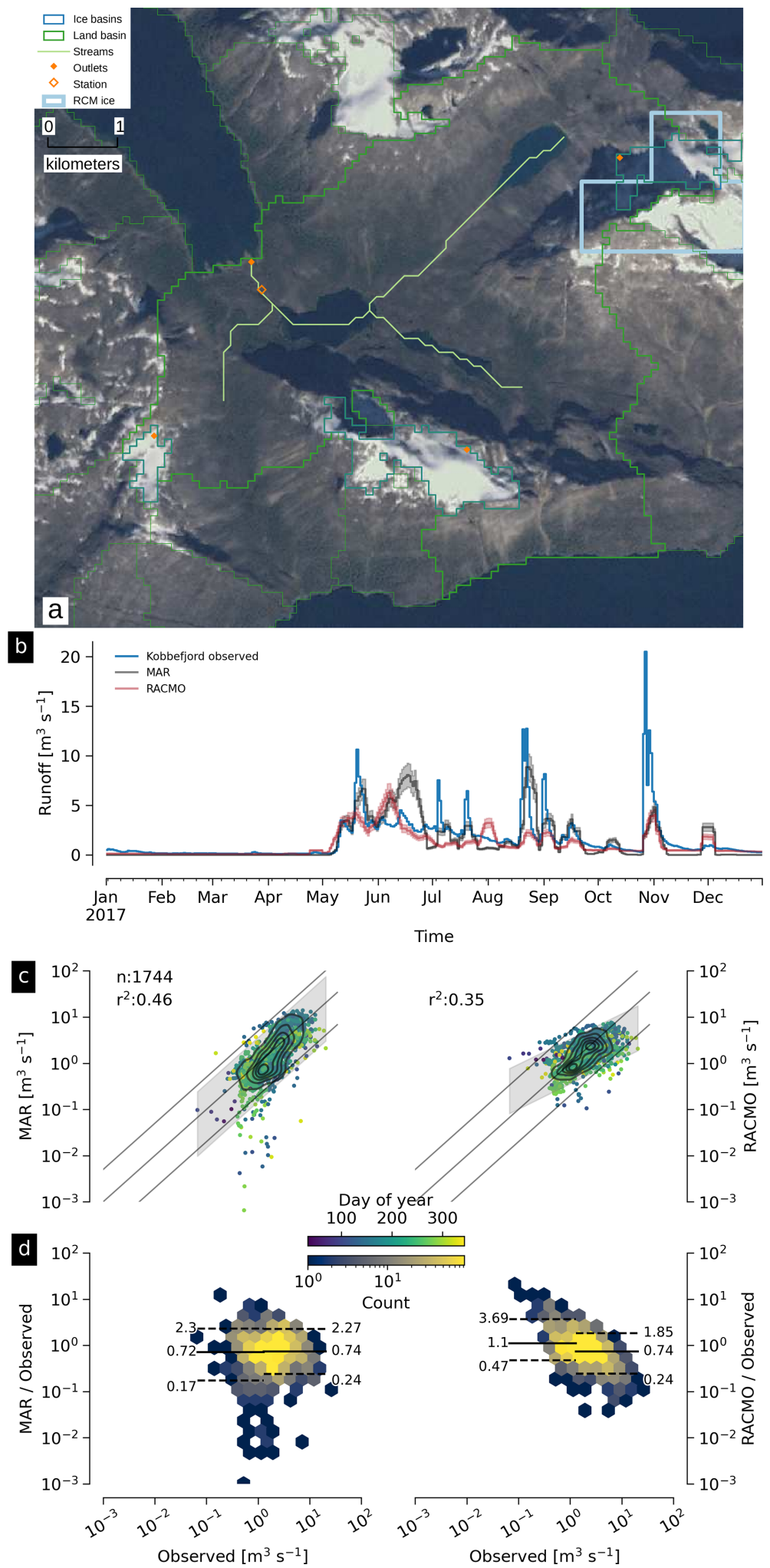

Figure 14. Graphical summary of Kobbefjord outlet, basin, and discharge (Kb in Fig. 1). See Sect. 3.4 for a general overview of graphical elements and Sect. 4.2.5 for discussion of the Kobbefjord basin. Basemap from Howat et al. (2014) and Howat (2017a). 


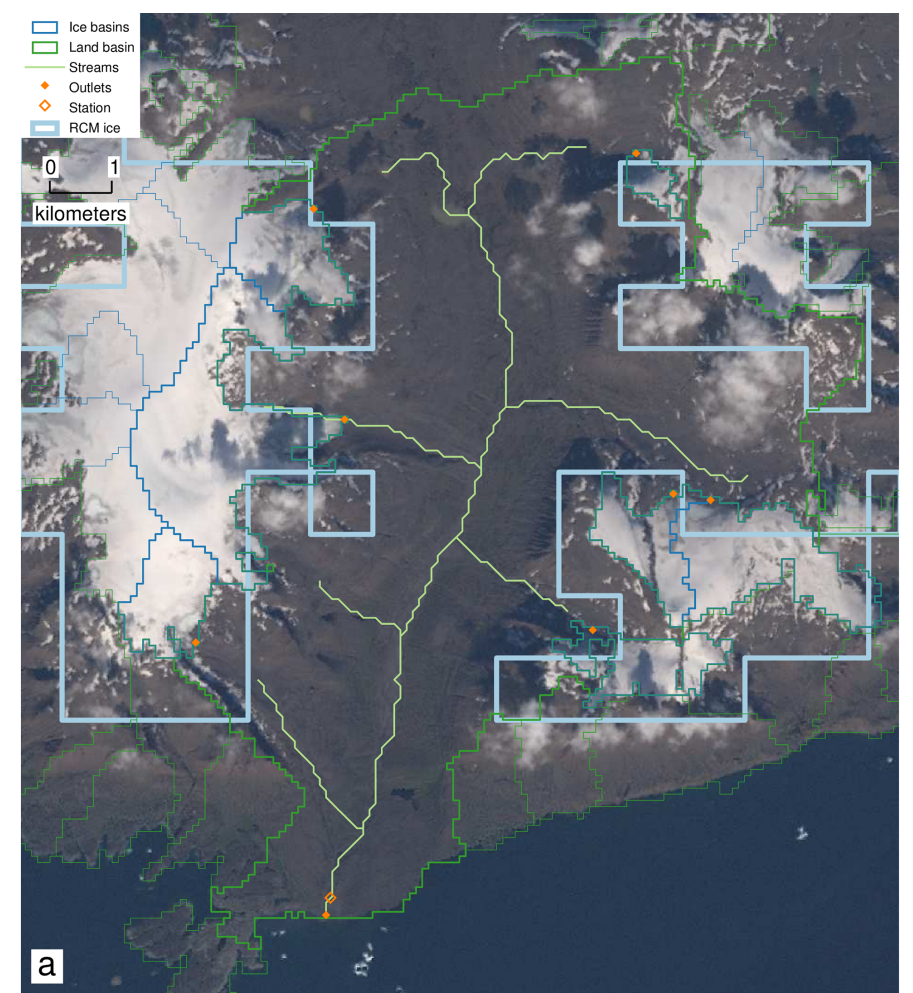

b
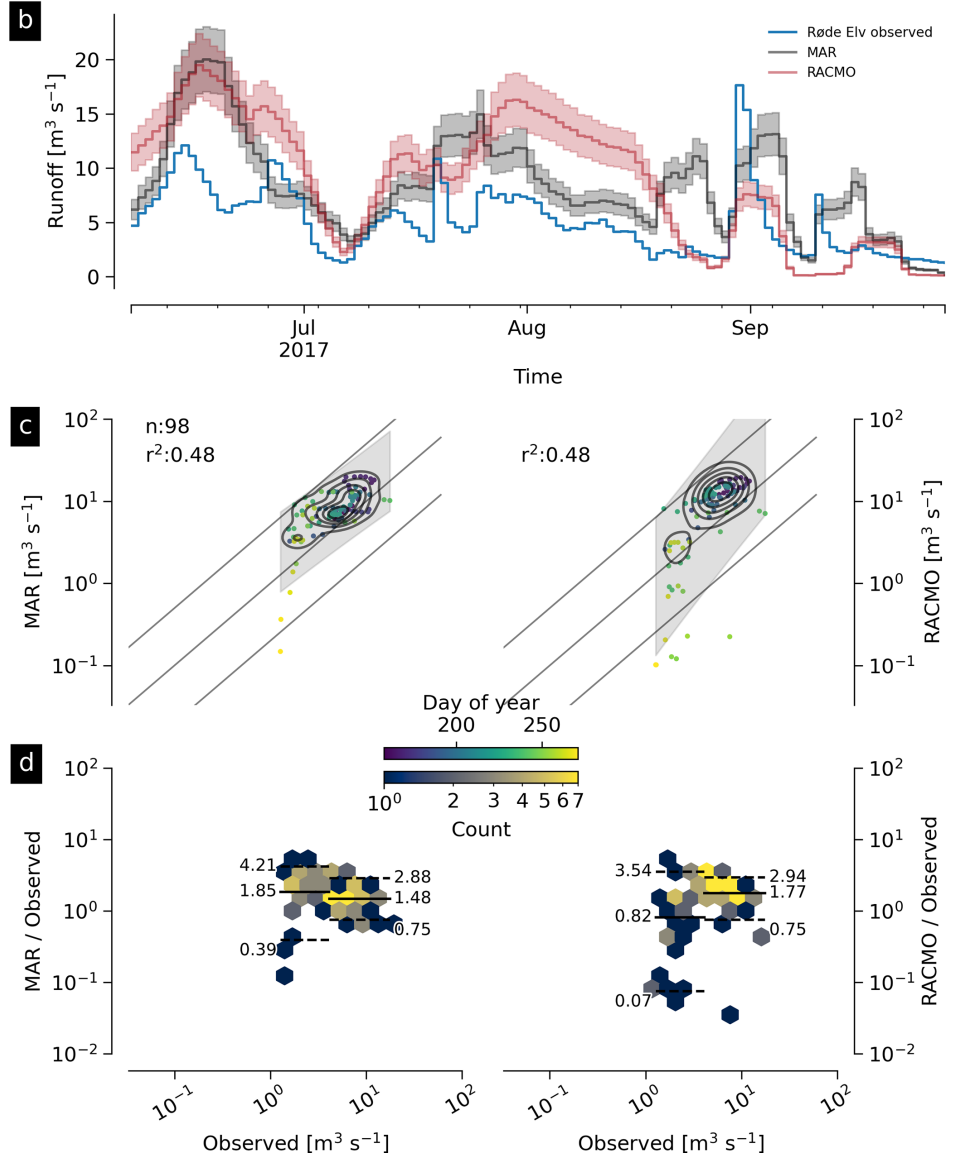

Figure 15. Graphical summary of Røde Elv outlet, basin, and discharge (R in Fig. 1). See Sect. 3.4 for a general overview of graphical elements and Sect. 4.2.6 for discussion of the Røde Elv basin. Basemap from Howat et al. (2014) and Howat (2017a). 

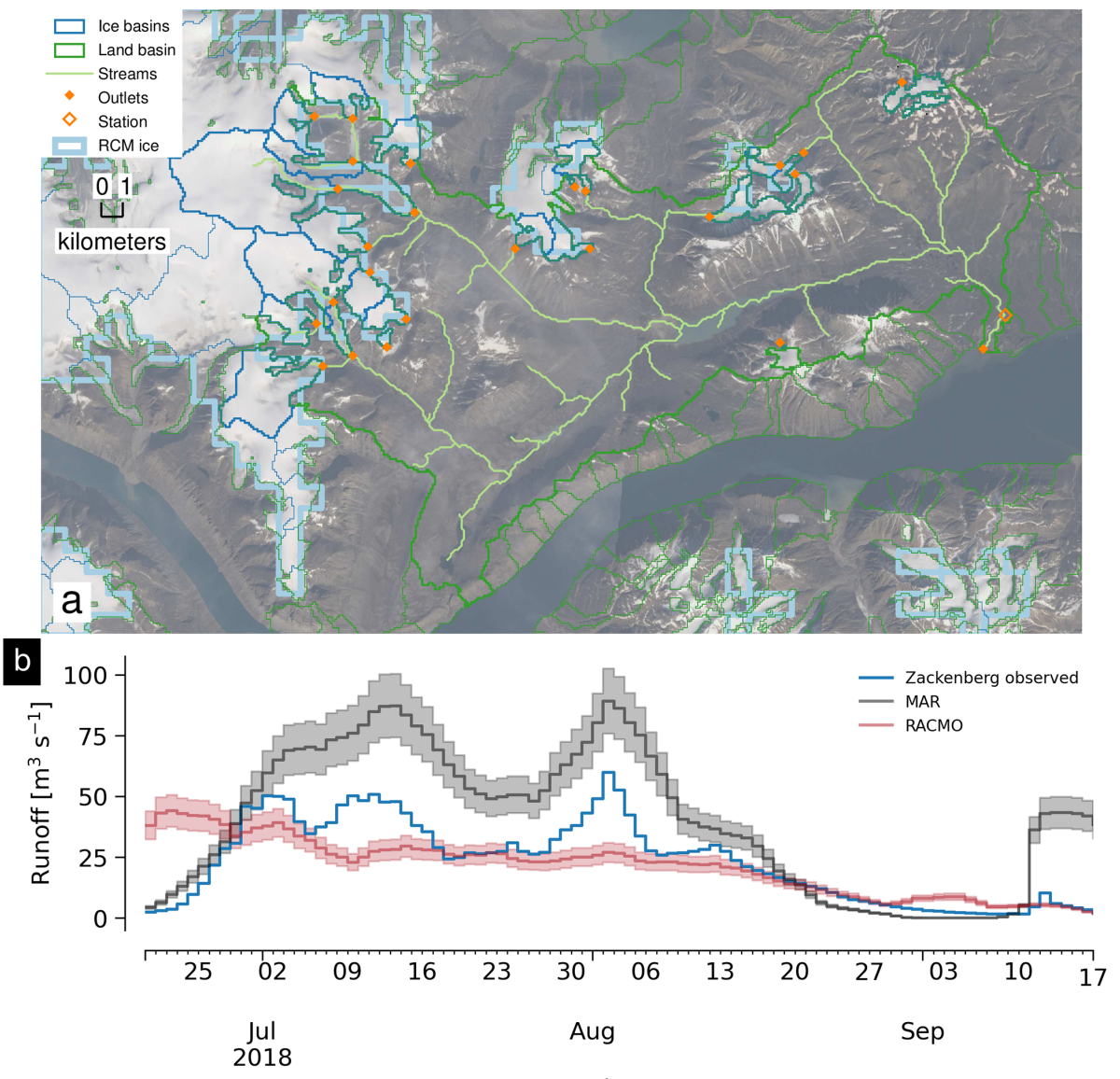

Time
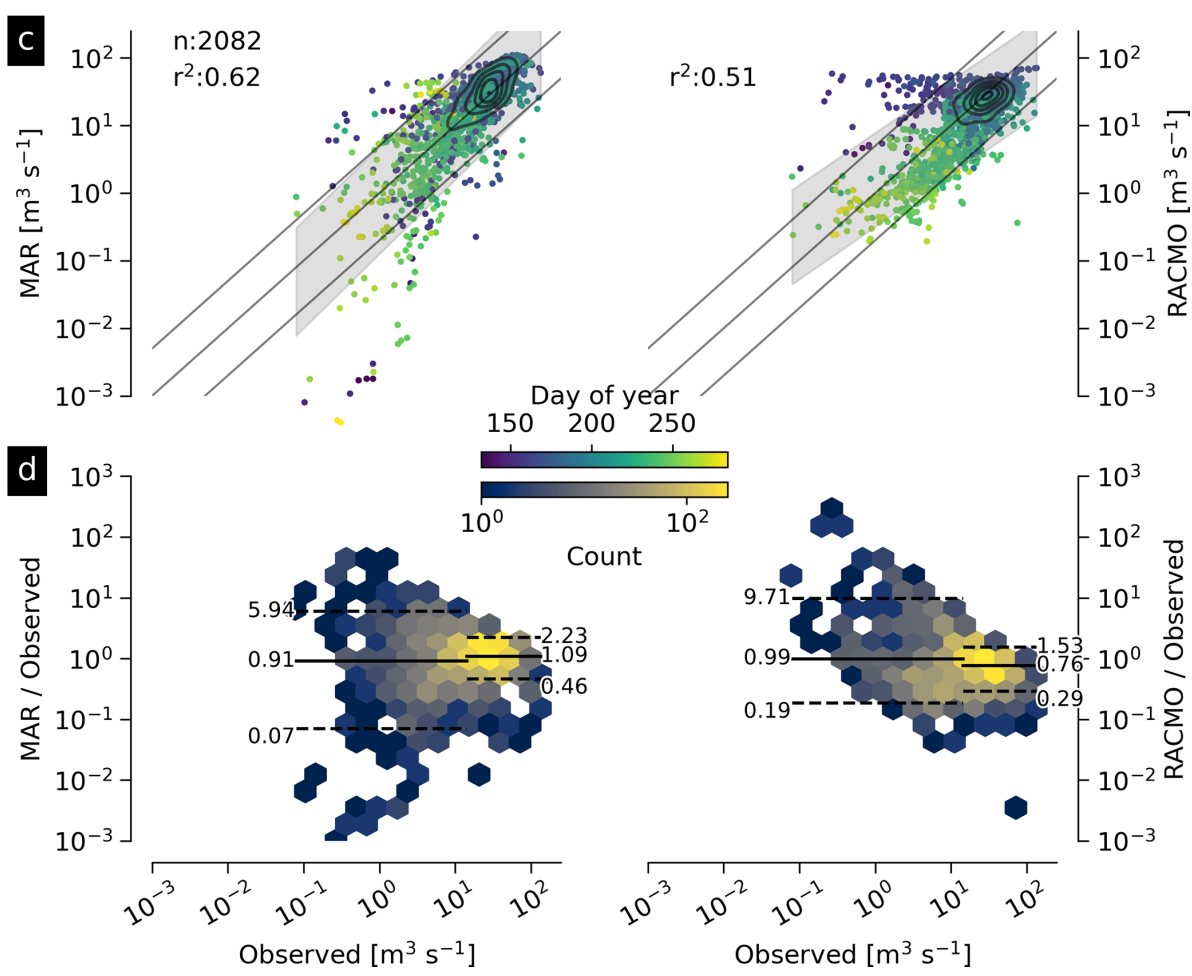

Figure 16. Graphical summary of Zackenberg outlet, basin, and discharge ( $Z$ in Fig. 1). See Sect. 3.4 for a general overview of graphical elements and Sect. 4.2.6 for discussion of the Zackenberg basin. Basemap from Howat et al. (2014) and Howat (2017a). 


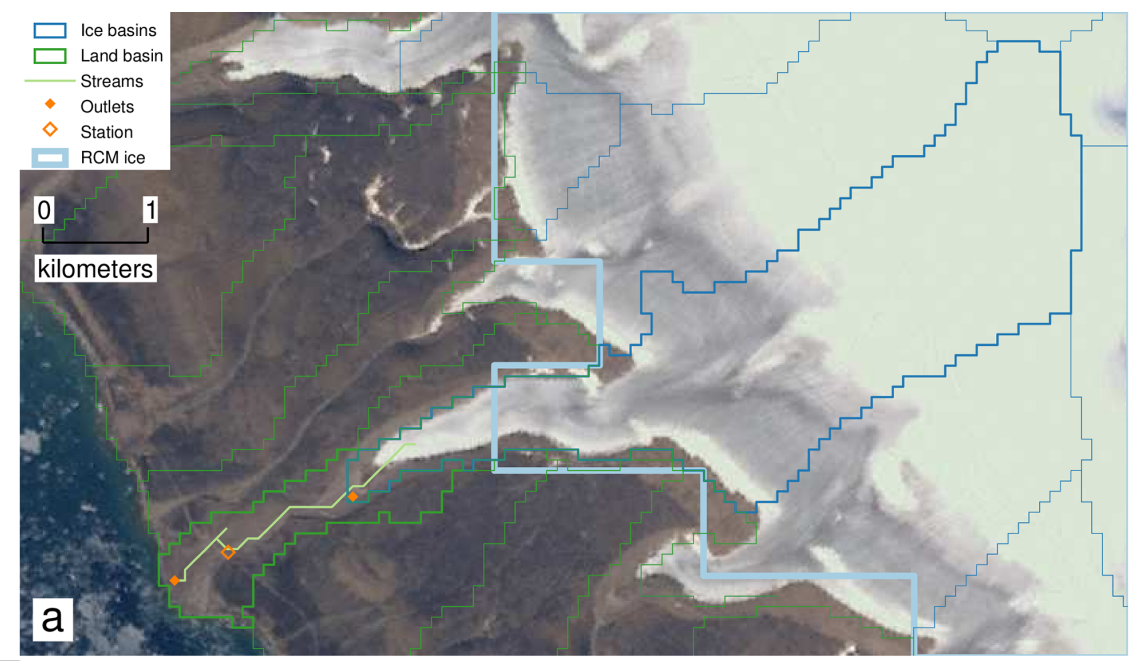

b

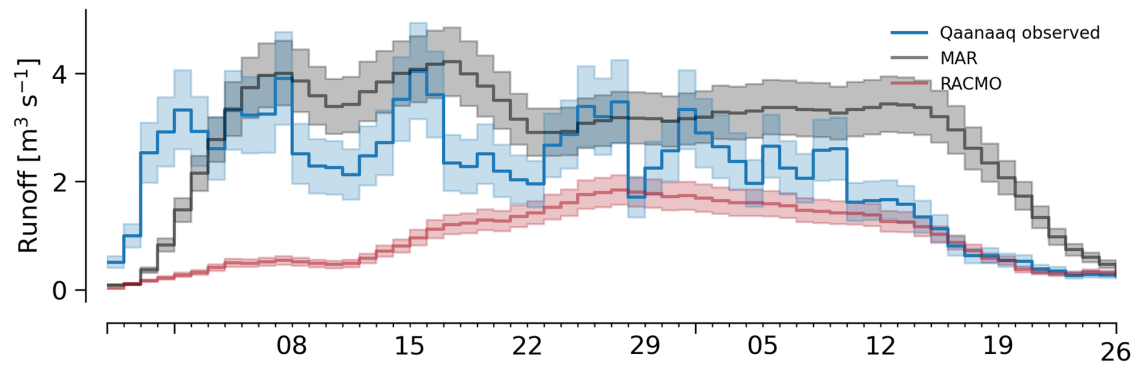
$\underset{2019}{\mathrm{Jul}}$ Aug Time
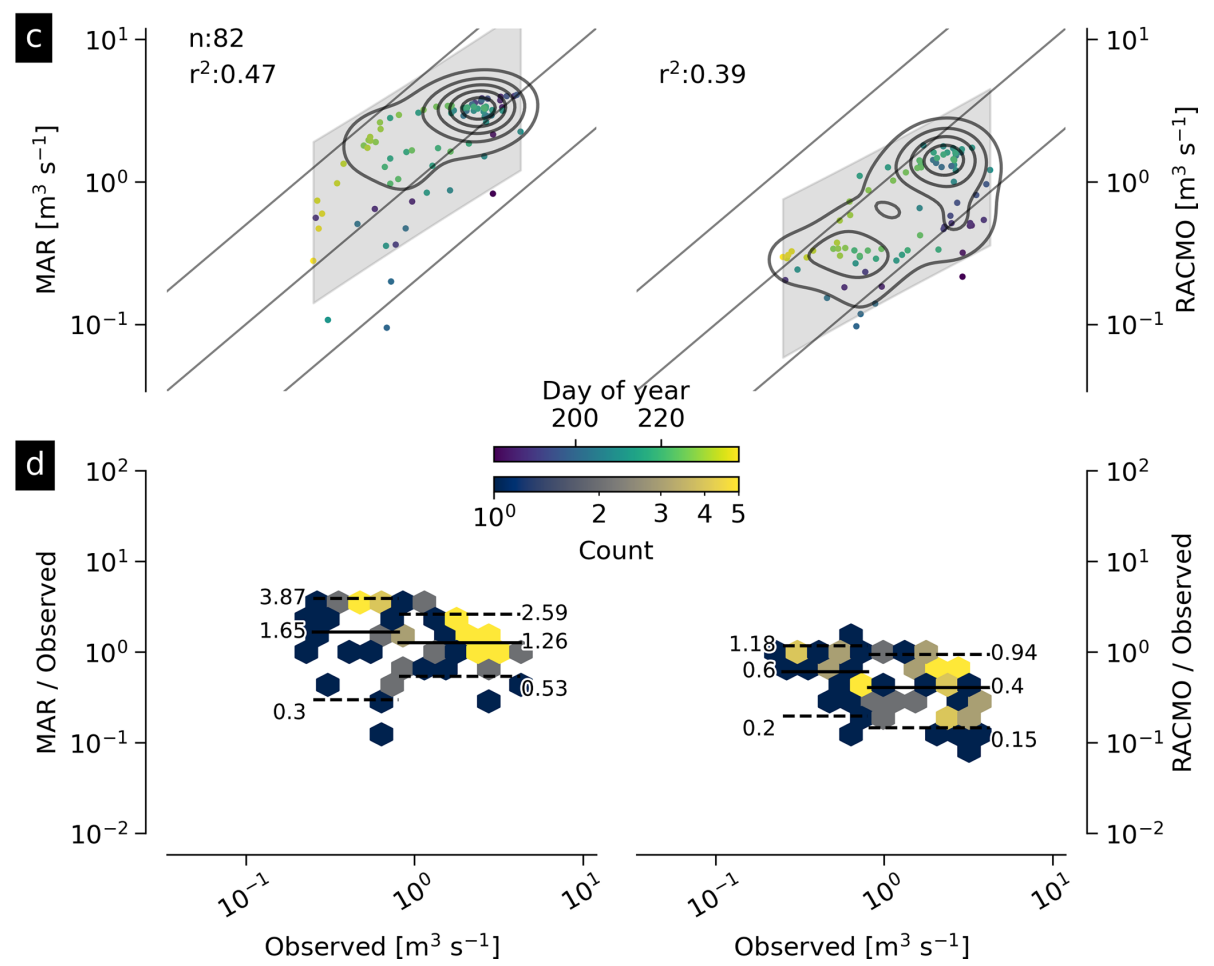

Figure 17. Graphical summary of Qaanaaq outlet, basin, and discharge (Q in Fig. 1). See Sect. 3.4 for a general overview of graphical elements and Sect. 4.2.6 for discussion of the Qaanaaq basin. Basemap from Howat et al. (2014) and Howat (2017a). 


\subsubsection{Basin uncertainty}

Basin uncertainty is a function of the subglacial routing assumptions (the $k$ parameter in Eq. 2, which in reality varies in both space and time). However, basin uncertainty does not necessary translate to discharge uncertainty. For example, when comparing two $k$ simulations, a large basin in simulation $k_{0}$ may change only its outlet by a few grid cells in $k_{1}$. A small micro-basin may appear in $k_{1}$ with its outlet in the same grid cell as the large $k_{0}$ outlet. The large change in discharge between the two outlets at the same location in $k_{0}$ and $k_{1}$ is not an appropriate estimate of uncertainty - rather the large basin in $k_{0}$ should be compared with the almost entirely overlapping large basin in $k_{1}$ with the different outlet. This fluidity of basins and outlets between $k$ scenarios makes it almost impossible to define, identify, and compare basins between scenarios, unless working manually with individual basins (as we did, for example, at the Leverett Glacier observation location, modeled upstream basin, and adjusted upstream basin; see Sect. 4.2.3).

Another example has a large basin in simulation $k_{0}$ and a similarly large basin in simulation $k_{1}$ draining out of the same grid cell, but overlapping only at the outlet grid cell. Upstream the two do not overlap and occupy different regions of the ice sheet. These two basins sharing one outlet (between different $k$ simulations) could have similar discharge. Put differently, although inland grid cells may change their outlet location by large distances under different routing assumptions (Fig. 2), that does not imply upstream basin area changes under different routing assumptions. Large changes in upstream catchment area are possible (Chu et al., 2016), but we note Chu et al. (2016) highlight changes at only a few outlets and under the extreme scenario of $k=1.11$ describing an overpressured system. Because $\rho_{\mathrm{w}} / \rho_{\mathrm{i}}=1.09$, setting $k=1.09$ reduces Eq. (2) to $h=z_{\mathrm{s}}$ and is equivalent to an overpressured system with surface routing of the water. In a limited examination comparing our results with $k \in$ $[0.8,0.9,1.0]$, we did not detect basins with large changes in upstream area. In addition, all time series graphics show the mean RCM discharge for $k=1.0$, but the uncertainty among all three $k$ values (not shown) is small enough that it is difficult to distinguish the three separate uncertainty bands - the difference between RCMs or between RCMs and observations is much larger than uncertainty from the $k$ parameter.

The above issues are specific to ice basins. Land basin outlets do not change location, and the range of upstream runoff from different $k$ simulations to a land outlet provides one metric of uncertainty introduced by the $k$ parameter. This uncertainty among all three $k$ values is small at ice margin outlets. It is even smaller at land outlets which act as spatial aggregators and increase the signal-to-noise ratio.

Below, we discuss the known uncertainties, ranging from least to most uncertain.

The basins presented here are static approximations based on the $100 \mathrm{~m}$ DEM of a dynamic system. Land basin bound- aries are likely to be more precise and accurate than ice basins because the land surface is better resolved, has larger surface slopes, has negligible subsurface flow, and is less dynamic than the ice surface. Even if basins and outlets seem visually correct from the $100 \mathrm{~m}$ product, the basin outline still has uncertainty on the order of hundreds of meters and will therefore include many minor errors and nonphysical properties, such as drainage basin boundaries bisecting lakes. However, all artifacts we did find are significantly smaller than the $1 \mathrm{~km}^{2}$ grid of the RCM inputs. We do not show but note that when doing the same work with the $150 \mathrm{~m}$ BedMachine land surface DEM, some basins change their outlet locations significantly - draining on the opposite side of a spit or isthmus and into a different fjord than the streams do when observed in satellite imagery. We have not observed these errors in streams and basins derived from the $100 \mathrm{~m}$ ArcticDEM in a visual comparison with Google Earth, although they may still exist.

Moving from land basins to subglacial ice basins, the uncertainty increases because subglacial routing is highly dynamic on timescales from minutes to seasons (e.g., Werder et al., 2013). This dynamic system may introduce large spatial changes in outflow location (water or basin "piracy", Ahlstrøm et al., 2002, Lindbäck et al., 2015, and Chu et al., 2016), but Stevens et al. (2018) suggests basins switching outlet locations may not be as common as earlier work suggests, and our sensitivity analysis suggests that, near the margin where the majority of runoff occurs, outlet location often changes by less than $10 \mathrm{~km}$ under different routing assumptions (Fig. 2). The largest (>100 km) changes in outlet location in Fig. 2 occur when the continental or ice flow divides move, and one or two of the $k$ scenario(s) drain cells to an entirely different coast or sector of the ice sheet.

The regions near the domain edges - both the land coast and the ice margin - are covered by many small basins, and in this work basins $<1 \mathrm{~km}^{2}$ are absorbed into their largest neighbor (see Methods section). By definition these basins are now hydraulically incorrect. An example can be seen in the Zackenberg basin (Fig. 16a, southwest corner of the basin), where one small basin on the southern side of a hydraulic divide was absorbed into the large Zackenberg basin that should be defined by and limited to the northern side of the mountain range.

Near the ice margin quality issues exist. At the margin, many of the small basins (absorbed or not) may be incorrect because the bed uncertainty is larger relative to the ice thickness, and therefore uncertainty has a larger influence on routing. Minor mask misalignments may cause hydraulic jumps (waterfalls) at the margin, or sinks that then need to be filled by the algorithm, and may overflow (i.e., the stream continues onward) somewhere at the sink edge different from the location of the real stream. The solution for individual outlets is to visually examine modeled outlet location, nearby streams in satellite imagery, and the area of upstream catchments, as we did for the Leverett Glacier outlet (Sect. 4.2.3). 
Alternatively, selecting several outlets in an area will likely include the nearby correct outlet. This can be automated and an effective method to aggregate all the micro-ice basins that occur at the domain edge is to select the downstream land basin associated with one ice outlet and then all upstream ice outlets for that land basin.

\subsubsection{RCM uncertainty}

In addition to the basin delineation issues discussed above, the runoff product from the RCMs also introduces uncertainty into the product generated here. The RCM input products do not provide formal time- or space-varying error estimates but of course do contain errors because they represent a simplified and discretized reality. RCM uncertainty is shown here with a value of $\pm 15 \%$. The MAR uncertainty comes from an evaluation by the Greenland SMB Model Intercomparison Project (GrSMBMIP; Fettweis et al., 2020) that examined the uncertainty of modeled SMB for $95 \%$ of the 10767 in situ measurements over the main ice sheet. The mean bias between the model and the measurements was $15 \%$ with a maximum of $1000 \mathrm{mmWE} \mathrm{yr}^{-1}$. GrSMBMIP uses integrated values over several months of SMB, suggesting larger uncertainty of modeled runoff at the daily timescale. The RACMO uncertainty comes from an estimated average $5 \%$ runoff bias in RACMO2.3p 2 compared to annual cumulative discharge from the Watson River (Noël et al., 2019). The bias increases to a maximum of $20 \%$ for extreme runoff years (e.g., 2010 and 2012), so here we select $15 \%$, a value between the reported $5 \%$ and the maximum $20 \%$ that matches the MAR uncertainty. We display $\pm 15 \%$ uncertainty in the graphics here and suggest this is a minimum value for daily runoff data.

The $15 \%$ RCM uncertainty is represented graphically in the time series plots when comparing to each of the observations. It is not shown in the scatter plots because the log-log scaling and many points make it difficult to display. In the time series plots, we show the mean value from the $k=1.0$ scenario and note that discharge from the other two $k$ scenarios covered approximately the same range.

\subsubsection{Observational uncertainty}

When comparing against observations, additional uncertainty is introduced because the stage-discharge relationship is neither completely precise nor accurate. We use published observation uncertainty when it exists. Only two observational data sets come with uncertainty: Watson River and Qaanaaq. Similar to the RCM uncertainty, they are displayed in the time series but not in the scatter plots.

\subsubsection{Mitigating uncertainties}

Traditional uncertainty propagation is further complicated because it is not clear to what extent the three uncertainties (observational, RCM, and routing model) should be treated as independent from each other - all three uncertainties are likely to show some correlation with elevation, slope, air temperature, or other shared properties or processes.

Many of the uncertainties discussed here can be mitigated by increasing the signal-to-noise ratio of the product. Because we provide a high spatial and temporal resolution product, this is equivalent to many signals, each of which has some uncertainty (noise). Averaging results spatially or temporally, if possible for a downstream use of this product, will increase the signal-to-noise ratio and reduce uncertainty.

For example, because we provide basins for the entire ice sheet, total discharge is not subject to basin uncertainty. Any error in the delineation of one basin must necessarily be corrected by the inclusion (if underestimate) or exclusion (if overestimate) of a neighboring basin, although neighboring basins may introduce their own errors. Therefore, summing basins reduces the error introduced by basin outline uncertainty and should be done if a downstream product does not need an estimate of discharge from a single outlet. This feature is built-in to coastal outlet discharge, which is not as sensitive to our routing algorithm as ice margin outlet discharge because most coast outlets include a range of upstream ice margin outlets (e.g., Fig. 7 vs. Fig. 9). Conversely, at the ice margin, outlet location and discharge volume is more uncertain than at the land coast. However, most runoff is generated near the ice margin, and as runoff approaches the margin, there are fewer opportunities to change outlet location (Fig. 2).

Our coverage algorithm (Sect. 3.3) only fills in glaciated regions that have at least some RCM coverage. When working with basins that have glaciated areas and no RCM coverage as in the case for all four of the GEM outlets near Nuuk, discharge could be approximated by estimating discharge from the nearest covered glaciated area with a similar climatic environment.

Temporally, errors introduced by this study's assumption of instantaneous discharge can be reduced by summing or averaging discharge over larger time periods, or applying a lag function to the time series as done here and in van As et al. (2017). Although a given volume of water may remain in storage long term, if one assumes that storage is in roughly steady state, then long-term storage shown by, for example, dye trace studies can be ignored - the volume with the dye may be stored, but a similar volume should be discharged in its place.

\subsubsection{Quality control}

The scale of the data are such that manual editing to remove artifacts is time and cost prohibitive. Here we provide one example of incorrect metadata. The elevation of each outlet is included as metadata by looking up the bed elevation in the BedMachine data set at the location of each outlet. Errors in 

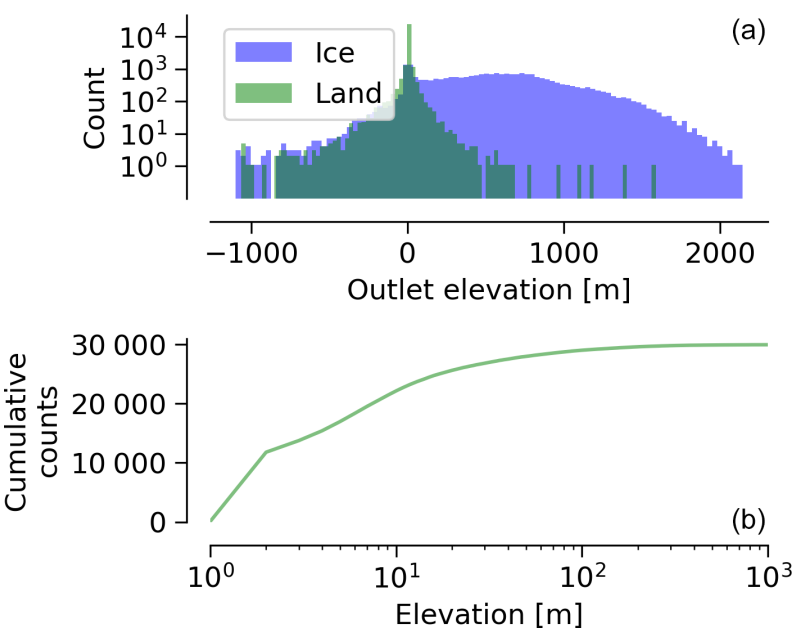

Figure 18. (a) Histogram of outlet elevations. (b) Cumulative distribution of absolute land outlet elevation. More than $75 \%$ of land outlets occur within $\pm 10 \mathrm{~m}$ and $90 \%$ within $\pm 30 \mathrm{~m}$.

BedMachine or in the outlet location (defined by the GIMP ocean mask) introduce errors in outlet elevation.

A large basin in NW Greenland has metadata outlet elevation $>0$ (gray in Fig. 1) but appears to be marine terminating when viewed in satellite imagery. Elsewhere the landvs. marine-terminating color coding in Fig. 1 appears to be mostly correct, but this view only provides information about the sign of the elevation and not the magnitude (i.e., if the reported depth is correct). Ice outlets can occur above, at, or below $0 \mathrm{~m}$. It is easier to validate the land-terminating basins, which should in theory all have an outlet elevation of $0 \mathrm{~m}$. That is not the case (Fig. 18). It is possible for land outlets to be correctly assigned an elevation $>0 \mathrm{~m}$, if a land basin outlet occurs at a waterfall off a cliff (as might occur the edges of Petermann fjord) or due to DEM discretization of steep cells. However, most of the land outlets at elevations other than 0 are likely due to mask misalignment placing a section of coastline in a fjord (negative land elevation) or inland (positive land elevation). The bulk of land discharge (75\%) occurs within $0 \pm 10 \mathrm{~m}$ elevation and $90 \%$ within $0 \pm 30 \mathrm{~m}$ elevation (Fig. 18).

\subsection{Other sources of freshwater}

The liquid water discharge product provided here is only one source of freshwater that leaves the ice sheet and affects fjords and coastal seas. The other primary freshwater source is iceberg calving and submarine melt at the ice/ocean boundary of marine-terminating glaciers. A companion to the liquid water discharge product introduced here is provided by Mankoff et al. (2019, 2020), which estimates solid ice volume flow rates across gates near marine-terminating glaciers. That downstream ice enters fjords as either calving icebergs or liquid water from submarine melting.
Both this product and Mankoff et al. (2020) provide liquid or solid freshwater volume flow rates at outlets (this product) or grounding lines (Mankoff et al., 2020), but actual freshwater discharge into a fjord occurs at a more complicated range of locations. Solid ice melts throughout the fjord and beyond (e.g., Enderlin et al., 2016; Moon et al., 2017), and the freshwater discharge presented here may enter at the reported depth (Sect. 4.3.6) but rapidly rises up the ice front and eventually flows into the fjord at some isopycnal (see Mankoff et al., 2016). The eventual downstream location of the fresh water is not addressed in this work.

Freshwater inputs directly to the water surface are also not included in this product. The flux (per square meter) to the water surface should be similar to the flux to the non-icecovered land surface - assuming the orographic effects on precipitation produce similar fluxes to the near-land water surface.

Finally, basal melt from (1) geothermal heating (e.g., Fahnestock et al., 2001), (2) frictional heating (e.g., Echelmeyer and Harrison, 1990), and (3) viscous heat dissipation from runoff (see Mankoff and Tulaczyk, 2017) contributes additional discharge (see for example Jóhannesson et al., 2020) to the surface melt. Geothermal and frictional heating are approximately in steady state and contribute freshwater throughout the winter months.

\subsection{Summary}

Of the 20 comparisons between the two RCMs and the 10 observations, we note the following.

- In general this product shows good agreement between observations and the modeled discharge from the RCM runoff routed to the outlets, when comparing across multiple basins, especially when ignoring small basins with small glaciers that are not included in the RCMs (Fig. 3). The agreement is not as good when estimating the discharge variability within individual basins. From this, the product is more appropriately used to estimate the magnitude of the discharge from any individual basin, and perhaps provide some idea of the statistical variability, but not necessarily the precise amount of discharge for any specific day, because routing delays are neglected.

- The majority of the 20 comparisons have the $5 \%$ to $95 \%$ prediction interval between scales of $1: 5$ and $5: 1$. From this, the model results match observations within plus or minus a factor of 5, or half an order of magnitude. Put differently, the daily RCM values for single or few basins have an uncertainty of $+500 \%$ or $-80 \%$.

- The uncertainty of $+500 \% /-80 \%$ is for "raw" data: daily discharge for one or few basins with a simple temporal smooth. When averaging spatially or temporally 
over larger areas or longer times, uncertainty decreases (Sect. 4.3). For example, when moving from daily data (Fig. 3) to annual sums (Fig. 4), the uncertainty is reduced to $+100 \% /-50 \%$.

- The two RCMs agree best with each other for the three observations dominated by large ice domains (Watson River, Sect. 4.2.2 and Fig. 7; Leverett Glacier, Sect. 4.2.3 and Fig. 9, which is a subset of the Watson River basin; and Kiattuut Sermiat, Sect. 4.2.4 and Fig. 10). RCMs agree best with observations for icedominated basins with well-resolved bed topography in BedMachine (i.e., correct basins modeled in this work) - here only Leverett Glacier (Sect. 4.2.3 and Fig. 9) meets this criterion.

- Runoff errors increase with low discharge (panels $d$ in Figs. 7, 9 to 17).

- For land basins, subglacial routing errors no longer exist, basins are well defined, and errors are due to neglecting runoff delays or the RCM estimates of runoff.

- For ice basins, errors are dominated by basin uncertainty. Errors between similar-sized and neighboring basins are likely to offset and may even cancel each other. Even so, a conservative treatment might consider errors between basins as random and reduce by the sum of the squares when summing discharge from multiple similar-sized and neighboring basins.

\section{Product description}

These data contain a static map of Greenland's hydrological outlets, basins, and streams and a times-series of discharge from each outlet.

The output data are provided in the following formats: the stream data are provided as a GeoPackage standard GIS product and a metadata CSV that includes the stream type (start or intermediate segment), network, stream alongflow length, stream straight length, sinuosity, source elevation, outlet elevation, and a variety of stream indices such as the Strahler, Horton, Shreve, Hack, and other parameters (Jasiewicz and Metz, 2011). We note that the subglacial streams are unvalidated with respect to actual subglacial conduits, and they should be used with caution. The outlet data are also provided as a GeoPackage and CSV, each of which include the outlet ID (linked to the basin ID), the longitude, latitude, EPSG:3413 $x$ and $y$, and the outlet elevation. The outlet elevation is the BedMachine bed elevation at the outlet location, and users should be aware of quality issues identified in Sect. 4.3.6. The ice outlet metadata includes the ID, longitude, latitude, $x$, and $y$ of the downstream land outlet, if one exists. The basin product GeoPackage includes the geospatial region that defines the basin. The metadata CSV includes the basin ID (linked to the outlet ID) and the area of each basin. The time series discharge product is provided as four NetCDF files per year, one for each domain (ice margin and land coast) and one for each RCM (MAR and RACMO). The NetCDF files contain an unlimited time dimension, usually containing 365 or $366 \mathrm{~d}$; much of the same metadata as the outlets CSV file, including the outlet (also known as station) ID, the latitude, longitude, and elevation of the outlet; and a runoff variable with dimensions (station, time) and units of cubic meters per second $\left(\mathrm{m}^{3} \mathrm{~s}^{-1}\right)$.

\subsection{Database access software}

The data can be accessed with custom code from the raw data files. However, to support downstream users we provide a tool to access the outlets, basins, and discharge for any region of interest (ROI). The ROI can be a point, a list describing a polygon, or a file, with units in longitude and latitude (EPSG:4326) or meters (EPSG:3413). If the ROI includes any land basins, an option can be set to include all upstream ice basins and outlets, if they exist. The script can be called from the command line (CLI) and returns CSV formatted tables or within Python and returns standard Python data structures (from the GeoPandas or xarray package).

For example, to query for discharge at one point $\left(50.5^{\circ} \mathrm{W}\right.$, $67.2^{\circ} \mathrm{N}$ ), the following command is issued:

python ./discharge.py -base

. Ifreshwater -roi=-50.5,67.2 -discharge,

where discharge.py is the provided script, - Ifreshwater is the folder containing the downloaded data, and -discharge tells the program to return RCM discharge (as opposed to -outlets which would return basin and outlet information). The program documentation and usage examples are available at http://github.com/mankoff/freshwater (last access: 6 November 2020) (Mankoff, 2020b).

Because the -upstream option is not set, the -discharge option is set, and the point is over land, the results of this command are a time series for the MAR and RACMO land discharge for the basin containing this point. A small subset (the first $10 \mathrm{~d}$ of June 2012) is shown as an example.

\begin{tabular}{rrr} 
time & MAR $_{\text {land }}$ & RACMO_land \\
\hline $2012-06-01$ & 0.043025 & 0.382903 \\
$2012-06-02$ & $5.5 \mathrm{e}-05$ & 0.095672 \\
$2012-06-03$ & $5 \mathrm{e}-05$ & 0.009784 \\
$2012-06-04$ & $9 \mathrm{e}-06$ & -0.007501 \\
$2012-06-05$ & 0.008212 & 0.007498 \\
$2012-06-06$ & 28.601947 & 0.607345 \\
$2012-06-07$ & 0.333926 & 0.05691 \\
$2012-06-08$ & 0.489437 & 0.204384 \\
$2012-06-09$ & 0.038816 & 0.167325 \\
$2012-06-10$ & $5.1 \mathrm{e}-05$ & 0.011415
\end{tabular}

If the upstream option is set, two additional columns are added: one for each of the two RCM ice domains. A maximum of six columns may be returned: $2 \mathrm{RCMs} \times(1$ land + 1 ice +1 upstream ice domain), because results are summed 
across all outlets within each domain when the script is called from the command line (summing is not done when the script is accessed from within Python).

If the -outlets option is set instead of the -discharge option, then results are a table of outlets. For example, moving $10^{\circ}$ east over the ice,

python . /discharge.py -base

. Ifreshwater -roi=-40.5,67.2 -outlets

results in the following.

\begin{tabular}{rrrrrrr} 
index & id & lon & lat & $x$ & $y$ \\
\hline 0 & 118180 & -38.071 & 66.33 & 313650 & -2580750 \\
1 & 67133 & -38.11 & 66.333 & 311850 & -2580650 \\
elev & domain & upstream & coast $_{\text {id }}$ & $\ldots$ & \\
\hline-78 & land & False & -1 & $\ldots$ & \\
-58 & ice & False & 118180 & $\ldots$ &
\end{tabular}

If the script is accessed from within Python, then the discharge option returns an xarray Dataset of discharge, without aggregating by outlet, and the out lets option returns a GeoPandas GeoDataFrame and includes the geospatial location of all outlets and outline of all basins, and can be saved to GIS-standard file formats for further analysis.

\section{Code and data availability}

The data from this work are available at https://doi.org/10.22008/promice/freshwater (Mankoff, 2020a).

The code and a website for postpublication updates are available at https:/github.com/mankoff/freshwater (Mankoff, 2020b), where we document changes to this work and use the GitHub Issues feature to collect suggested improvements, document those improvements as they are implemented, and document problems that made it through review. This version of the document is generated with git commit version $3241 \mathrm{e} 79$.

\section{Conclusions}

We provide a $100 \mathrm{~m}$ spatial resolution data set of streams, outlets, and basins, and a $1 \mathrm{~d}$ temporal resolution data set of discharge through those outlets for the entire ice sheet area from 1958 through 2019. Access to this database is made simple for nonspecialists with a Python script. Comparing the two RCM-derived discharge products to 10 gauged streams shows the uncertainty is approximately plus or minus a factor of 5 , or half an order of magnitude, or $+500 \% /-$ $80 \%$, when comparing daily discharge for single or few basins.

Because of the high spatial (individual basins) and temporal (daily) resolution, larger uncertainty exists than when working over larger areas or time steps. These larger areas and times can be achieved through spatial and temporal aggregation or by implementing a lag function.

This liquid freshwater volumetric flow rate product is complemented by a solid ice discharge product (Mankoff et al., 2020). Combined, these provide an estimate of the majority of freshwater (total solid ice and liquid) flow rates from the Greenland Ice Sheet into fjords and coastal seas, at high temporal resolution and process-level spatial resolution (i.e., glacier terminus for solid ice discharge, stream for liquid discharge).

This estimate of freshwater volume flow rate into Greenland fjords aims to support further studies of the impact of freshwater on ocean physical, chemical, and biological properties; fjord nutrient, sediment, and ecosystems; and larger societal impacts of freshwater on the fjord and surrounding environments. 


\section{Appendix A: Software}

This work was performed using only open-source software, primarily GRASS GIS (Neteler et al., 2012), CDO (Schulzweida, 2019), NCO (Zender, 2008), GDAL (GDAL/OGR contributors, 2020), and Python (Van Rossum and Drake Jr., 1995), in particular the Jupyter (Kluyver et al., 2016), dask (Dask Development Team, 2016; Rocklin, 2015), pandas (McKinney, 2010), geopandas (Jordahl et al., 2020), numpy (Oliphant, 2006), x-array (Hoyer and Hamman, 2017), and Matplotlib (Hunter, 2007) packages. The entire work was performed in Emacs (Stallman, 1981) using Org Mode (Schulte et al., 2012) on GNU/Linux and using many GNU utilities (see https: //github.com/mankoff/freshwater, Mankoff, 2020b). The parallel (Tange, 2011) tool was used to speed up processing. We used proj 4 (PROJ contributors, 2018) to compute the errors in the EPSG 3413 projection. The color map for Fig. 2 comes from Brewer (2020). All code used in this work is available in the supplemental online material. 
Author contributions. KDM produced this work and wrote the code and the text. XF and BN supplied RCM inputs. APA, WIC, DVA, and RSF helped with discussions of methods, quality control, or writing. KK and SS supplied Qaanaaq data. KL provided GEM data.

Competing interests. The authors declare that they have no conflict of interest.

Acknowledgements. DEMs were provided by the Polar Geospatial Center under NSF-OPP awards 1043681, 1559691, and 1542736. Data from the Greenland Ecosystem Monitoring (GEM) program were provided by Asiaq - Greenland Survey, Nuuk, Greenland. We thank Dorthe Petersen (Asiaq) for help with basin quality control. The editor and two anonymous reviewers provided valuable feedback and helped improve this paper (Anonymous, 2020a,b).

Financial support. Funding was provided by the Programme for Monitoring of the Greenland Ice Sheet (PROMICE). Parts of this work were funded by the INTAROS project under the European Union's Horizon 2020 research and innovation program under grant agreement no. 727890. Brice Noël was funded by NWO VENI grant VI.Veni.192.019.

Review statement. This paper was edited by Reinhard Drews and reviewed by two anonymous referees.

\section{References}

Ahlstrøm, A. P., Bøggild, C. E., Mohr, J. J., Reeh, N., Christensen, E. L., Olesen, O. B. and Keller, K.: Mapping of a hydrological ice-sheet drainage basin on the West Greenland ice-sheet margin from ERS-1/-2 SAR interferometry, iceradar measurement and modelling, Ann. Glaciol., 34, 309-314, https://doi.org/10.3189/172756402781817860, 2002.

Ahlstrøm, A. P., Petersen, D., Langen, P. L., Citterio, M., and Box, J. E.: Abrupt shift in the observed runoff from the southwestern Greenland ice sheet, Sci. Adv., 3, e1701169, https://doi.org/10.1126/sciadv.1701169, 2017.

Altman, D. G. and Bland, J. M.: Measurement in Medicine: The Analysis of Method Comparison Studies, Statistician, 32, 307, https://doi.org/10.2307/2987937, 1983.

An, S.-I., Kim, H., and Kim, B.-M.: Impact of freshwater discharge from the Greenland ice sheet on North Atlantic climate variability, Theor. Appl. Climatol., 112, 29-43, https://doi.org/10.1007/s00704-012-0699-6, 2012.

Anonymous: Interactive comment on "Greenland liquid waterrunoff from 1979 through 2017" by Kenneth D. Mankoff et al., Earth Syst. Sci. Data Discuss., https://doi.org/10.5194/essd2020-47-rc1, 2020a.

Anonymous: Interactive comment on "Greenland liquid waterrunoff from 1979 through 2017" by Kenneth D. Mankoff et al., Earth Syst. Sci. Data Discuss., https://doi.org/10.5194/essd2020-47-rc2, 2020b.
Balmonte, J. P., Hasler-Sheetal, H., Glud, R. N., Andersen, T. J., Sejr, M. K., Middelboe, M., Teske, A., and Arnosti, C.: Sharp contrasts between freshwater and marine microbial enzymatic capabilities, community composition, and DOM pools in a NE Greenland fjord, Limnol. Oceanogr., 65, 77-95, https://doi.org/10.1002/lno.11253, 2019.

Bamber, J. L., Griggs, J. A., Hurkmans, R. T. W. L., Dowdeswell, J. A., Gogineni, S. P., Howat, I., Mouginot, J., Paden, J., Palmer, S., Rignot, E., and Steinhage, D.: A new bed elevation dataset for Greenland, The Cryosphere, 7, 499-510, https://doi.org/10.5194/tc-7-499-2013, 2013.

Bamber, J. L., Tedstone, A. J., King, M. D., Howat, I. M., Enderlin, E. M., van den Broeke, M. R., and Noel, B.: Land Ice Freshwater Budget of the Arctic and North Atlantic Oceans: 1. Data, Methods, and Results, J. Geophys. Rese.-Oceans, 123, 1827-1837, https://doi.org/10.1002/2017jc013605, 2018.

Beckmann, J., Perrette, M., Beyer, S., Calov, R., Willeit, M., and Ganopolski, A.: Modeling the response of Greenland outlet glaciers to global warming using a coupled flow line-plume model, The Cryosphere, 13, 2281-2301, https://doi.org/10.5194/tc-13-2281-2019, 2019.

Bendtsen, J., Mortensen, J., Lennert, K., and Rysgaard, S.: Heat sources for glacial ice melt in a West Greenland tidewater outlet glacier fjord: The role of subglacial freshwater discharge, Geophys. Res. Lett., 65, 1535-1546, https://doi.org/10.1002/2015GL063846, 2015.

Brewer, C. A.: ColorBrewer.org Website, http://www.ColorBrewer. org, last access: 2 June 2020.

Catania, G. A., Stearns, L. A., Moon, T. A., Enderlin, E. M., and Jackson, R. H.: Future Evolution of Greenland's MarineTerminating Outlet Glaciers, J. Geophys. Res.-Earth, 125, e2018JF004873, https://doi.org/10.1029/2018jf004873, 2020.

Chu, W., Creyts, T. T., and Bell, R. E.: Rerouting of subglacial water flow between neighboring glaciers in West Greenland, J. Geophys. Res.-Earth, 121, 925-938, https://doi.org/10.1002/2015JF003705, 2016.

Citterio, M. and Ahlstrøm, A. P.: Brief communication "The aerophotogrammetric map of Greenland ice masses", The Cryosphere, 7, 445-449, https://doi.org/10.5194/tc-7-445-2013, 2013.

Citterio, M., Sejr, M. K., Langen, P. L., Mottram, R. H., Abermann, J., Hillerup Larsen, S., Skov, K., and Lund, M.: Towards quantifying the glacial runoff signal in the freshwater input to Tyrolerfjord-Young Sound, NE Greenland, Ambio., 46, 146159, https://doi.org/10.1007/s13280-016-0876-4, 2017.

Colgan, W., Rajaram, H., Anderson, R., Steffen, K., Phillips, T., Joughin, I. R., Zwally, H. J., and Abdalati, W.: The annual glaciohydrology cycle in the ablation zone of the Greenland ice sheet: Part 1. Hydrology model, J. Glaciol., 57, 697-709, 2011.

Cowton, T. R., Slater, D., Sole, A., Goldberg, D., and Nienow, P.: Modeling the impact of glacial runoff on fjord circulation and submarine melt rate using a new subgrid-scale parameterization for glacial plumes, J. Geophys. Res.-Oceans, 120, 796-812, https://doi.org/10.1002/2014JC010324, 2015.

Cowton, T. R., Todd, J. A., and Benn, D. I.: Sensitivity of tidewater glaciers to submarine melting governed by plume locations, Geophys. Res. Lett., 46, 11219-11227, https://doi.org/10.1029/2019g1084215, 2019. 
Crozier, J., Karlstrom, L., and Yang, K.: Basal control of supraglacial meltwater catchments on the Greenland Ice Sheet, The Cryosphere, 12, 3383-3407, https://doi.org/10.5194/tc-123383-2018, 2018.

Dask Development Team: Dask: Library for dynamic task scheduling, available at: https://dask.org (last access: 11 November 2020), 2016.

Delhasse, A., Kittel, C., Amory, C., Hofer, S., van As, D., S. Fausto, R., and Fettweis, X.: Brief communication: Evaluation of the near-surface climate in ERA5 over the Greenland Ice Sheet, The Cryosphere, 14, 957-965, https://doi.org/10.5194/tc14-957-2020, 2020.

Echelmeyer, K. and Harrison, W. D.: Jakobshavns IsbrÆ, West Greenland: Seasonal Variations in Velocity - or Lack Thereof, J. Glaciol., 36, 82-88, https://doi.org/10.3189/s0022143000005591, 1990.

Enderlin, E. M., Hamilton, G. S., Straneo, F., and Sutherland, D. A.: Iceberg meltwater fluxes dominate the freshwater budget in Greenland's iceberg-congested glacial fjords, Geophys. Res. Lett., 43, 11287-11294, https://doi.org/10.1002/2016gl070718, 2016.

Fahnestock, M., Abdalati, W., Joughin, I. R., Brozena, J., and Gogineni, P. S.: High geothermal heat flow, basal melt, and the origin of rapid ice flow in central Greenland, Science, 294, 2338-2342, https://doi.org/10.1126/science.1065370, 2001.

Fettweis, X., Box, J. E., Agosta, C., Amory, C., Kittel, C., Lang, C., van As, D., Machguth, H., and Gallée, H.: Reconstructions of the 1900-2015 Greenland ice sheet surface mass balance using the regional climate MAR model, The Cryosphere, 11, 1015-1033, https://doi.org/10.5194/tc-11-1015-2017, 2017.

Fettweis, X., Hofer, S., Krebs-Kanzow, U., Amory, C., Aoki, T., Berends, C. J., Born, A., Box, J. E., Delhasse, A., Fujita, K., Gierz, P., Goelzer, H., Hanna, E., Hashimoto, A., Huybrechts, P., Kapsch, M.-L., King, M. D., Kittel, C., Lang, C., Langen, P. L., Lenaerts, J. T. M., Liston, G. E., Lohmann, G., Mernild, S. H., Mikolajewicz, U., Modali, K., Mottram, R. H., Niwano, M., Noël, B., Ryan, J. C., Smith, A., Streffing, J., Tedesco, M., van de Berg, W. J., van den Broeke, M., van de Wal, R. S. W., van Kampenhout, L., Wilton, D., Wouters, B., Ziemen, F., and Zolles, T.: GrSMBMIP: intercomparison of the modelled 1980 2012 surface mass balance over the Greenland Ice Sheet, The Cryosphere, 14, 3935-3958, https://doi.org/10.5194/tc-14-39352020, 2020.

Fried, M., Carroll, D., Catania, G., Sutherland, D., Stearns, L., Shroyer, E., and Nash, J.: Distinct frontal ablation processes drive heterogeneous submarine terminus morphology, Geophys. Res. Lett., 46, 12083-12091, https://doi.org/10.1029/2019gl083980, 2019.

GDAL/OGR contributors: GDAL/OGR Geospatial Data Abstraction software Library, Open Source Geospatial Foundation, available at: https://gdal.org, last access: 11 November 2020.

Gillard, L. C., Hu, X., Myers, P. G., and Bamber, J. L.: Meltwater pathways from marine terminating glaciers of the Greenland ice sheet, Geophys. Res. Lett., 43, 10873-10882, https://doi.org/10.1002/2016g1070969, 2016.

GRASS Development Team: Geographic Resources Analysis Support System (GRASS GIS) Software, Open Source Geospatial Foundation, USA, available at: https://grass.osgeo.org (last access: 13 August 2020), 2018.
Hawkings, J., Wadham, J., Tranter, M., Lawson, E., Sole, A., Cowton, T., Tedstone, A., Bartholomew, I., Nienow, P., Chandler, D., and Telling, J.: The effect of warming climate on nutrient and solute export from the Greenland Ice Sheet, Geochemical Perspectives Letters, 1, 94-104, https://doi.org/10.7185/geochemlet.1510, 2015.

Hawkings, J., Wadham, J., Telling, J., Bagshaw, E., Beaton, A., Chandler, D., and Dubnick, A.: Proglacial discharge measurements, Kiattuut Sermiat glacier, south Greenland (near Narsarsuaq), Zenodo, https://doi.org/10.5281/zenodo.3685976, 2016 a.

Hawkings, J., Wadham, J., Tranter, M., Telling, J., Bagshaw, E., Beaton, A., Simmons, S.-L., Chandler, D., Tedstone, A., and Nienow, P.: The Greenland Ice Sheet as a hot spot of phosphorus weathering and export in the Arctic, Global Biogeochem., Cy., 30, 191-210, https://doi.org/10.1002/2015gb005237, 2016b.

Howat, I.: MEaSUREs Greenland Ice Mapping Project (GIMP) 2000 Image Mosaic, Version 1, NASA National Snow and Ice Data Center Distributed Active Archive Center, https://doi.org/10.5067/4RNTRRE4JCYD (last access: 4 April 2020), 2017a (updated 2018).

Howat, I.: MEaSUREs Greenland Ice Mapping Project (GIMP) Land Ice and Ocean Classification Mask, Version 1, NASA National Snow and Ice Data Center Distributed Active Archive Center, https://doi.org/10.5067/B8X58MQBFUPA (last access: 21 March 2019), 2017b.

Howat, I. M., Negrete, A., and Smith, B. E.: The Greenland Ice Mapping Project (GIMP) land classification and surface elevation data sets, The Cryosphere, 8, 1509-1518, https://doi.org/10.5194/tc-8-1509-2014, 2014.

Hoyer, S. and Hamman, J. J.: xarray: N-D labeled Arrays and Datasets in Python, Journal of Open Research Software, 5, 10, https://doi.org/10.5334/jors.148, 2017.

Hunter, J. D.: Matplotlib: A 2D graphics environment, Comput. Sci. Eng., 9, 90-95, 2007.

Jasiewicz, J. and Metz, M.: A new GRASS GIS toolkit for Hortonian analysis of drainage networks, Comput. Geosci., 37, 11621173, https://doi.org/10.1016/j.cageo.2011.03.003, 2011.

Jordahl, K., den Bossche, J. V., Wasserman, J., McBride, J., Fleischmann, M., Gerard, J., Tratner, J., Perry, M., Farmer, C., Hjelle, G. A., Gillies, S., Cochran, M., Bartos, M., Culbertson, L., Eubank, N., Bilogur, A., and maxalbert: geopandas/geopandas: v0.7.0, Zenodo, https://doi.org/10.5281/zenodo.3669853, 2020.

Jóhannesson, T., Pálmason, B., Hjartarson, Á., Jarosch, A., Magnússon, E., Belart, J., and Gudmundsson, M.: Non-surface mass balance of glaciers in Iceland, J. Glaciol., 66, 685-697, https://doi.org/10.1017/jog.2020.37, 2020.

Kamenos, N. A., Hoey, T. B., Nienow, P. W., Fallick, A. E., and Claverle, T.: Reconstructing Greenland ice sheet runoff using coralline algae, Geology, 40, 1095-1098, https://doi.org/10.1130/G33405.1, 2012.

Kanna, N., Sugiyama, S., Ohashi, Y., Sakakibara, D., Fukamachi, Y., and Nomura, D.: Upwelling of Macronutrients and Dissolved Inorganic Carbon by a Subglacial Freshwater Driven Plume in Bowdoin Fjord, Northwestern Greenland, J. Geophys. Res.-Biogeo., 123, 1666-1682, https://doi.org/10.1029/2017jg004248, 2018.

Kluyver, T., Ragan-Kelley, B., Pérez, F., Granger, B., Bussonnier, M., Frederic, J., Kelley, K., Hamrick, J., Grout, J., Corlay, S., Ivanov, P., Avila, D., Abdalla, S., and Willing, C.: 
Jupyter Notebooks - a publishing format for reproducible computational workflows, https://doi.org/10.3233/978-1-61499-6491-87, 2016.

Kondo, K. and Sugiyama, S.: Discharge measurement at the outlet stream of Qaanaaq Glacier in the summer 2017-2019, GEUS Data Center, https://doi.org/10.22008/hokkaido/data/meltwater_discharge/qaanaaq 2020.

Lampkin, D. J. and VanderBerg, J.: A preliminary investigation of the influence of basal and surface topography on supraglacial lake distribution near Jakobshavn Isbrae, western Greenland, Hydrol. Process., 25, 3347-3355, https://doi.org/10.1002/hyp.8170, 2011.

Langen, P. L., Mottram, R. H., Christensen, J. H., Boberg, F., Rodehacke, C. B., Stendel, M., van As, D., Ahlstrøm, A. P., Mortensen, J., Rysgaard, S., Petersen, D., Svendsen, K. H., Aalgeirsdóttir, G., and Cappelen, J.: Quantifying energy and mass fluxes controlling Godthåbsfjord freshwater input in a $5 \mathrm{~km}$ simulation (1991-2012), J. Climate, 28, 3694-3713, https://doi.org/10.1175/JCLI-D-14-00271.1, 2015.

Langley, K.: GEM river discharge measurements, GEUS Data Center, https://doi.org/10.22008/asiaq/data/meltwater_discharge/gem, 2020.

Lewis, S. M. and Smith, L. C.: Hydrologic drainage of the Greenland ice sheet, Hydrol. Process., 23, 2004-2011, https://doi.org/10.1002/hyp.7343, 2009.

Lindbäck, K., Pettersson, R., Doyle, S. H., Helanow, C., Jansson, P., Kristensen, S. S., Stenseng, L., Forsberg, R., and Hubbard, A. L.: High-resolution ice thickness and bed topography of a land-terminating section of the Greenland Ice Sheet, Earth Syst. Sci. Data, 6, 331-338, https://doi.org/10.5194/essd-6-331-2014, 2014.

Lindbäck, K., Pettersson, R., Hubbard, A. L., Doyle, S. H., van As, D., Mikkelsen, A. B., and Fitzpatrick, A. A.: Subglacial water drainage, storage, and piracy beneath the Greenland Ice Sheet, Geophys. Res. Lett., 42, 7606-7614, https://doi.org/10.1002/2015GL065393, 2015.

Liston, G. E. and Mernild, S. H.: Greenland freshwater runoff. Part I: A runoff routing model for glaciated and nonglaciated landscapes (HydroFlow), J. Climate, 25, 59976014, https://doi.org/10.1175/JCLI-D-11-00591.1, 2012.

Livingstone, S. J., Clark, C. D., Woodward, J., and Kingslake, J.: Potential subglacial lake locations and meltwater drainage pathways beneath the Antarctic and Greenland ice sheets, The Cryosphere, 7, 1721-1740, https://doi.org/10.5194/tc-7-17212013, 2013.

Mankoff, K. D.: Freshwater runoff, GEUS Dataverse, https://doi.org/10.22008/promice/freshwater, 2020a.

Mankoff, K. D.: Freshwater, GitHub, https://github.com/mankoff/ freshwater, last access: 10 August 2020b.

Mankoff, K. D. and Tulaczyk, S. M.: The past, present, and future viscous heat dissipation available for Greenland subglacial conduit formation, The Cryosphere, 11, 303-317, https://doi.org/10.5194/tc-11-303-2017, 2017.

Mankoff, K. D., Straneo, F., Cenedese, C., Das, S. B., Richards, C. G., and Singh, H.: Structure and dynamics of a subglacial discharge plume in a Greelandic fjord, J. Geophys. Res.-Oceans, 121, 8670-8688, https://doi.org/10.1002/2016JC011764, 2016.
Mankoff, K. D., Colgan, W., Solgaard, A., Karlsson, N. B., Ahlstrøm, A. P., van As, D., Box, J. E., Khan, S. A., Kjeldsen, K. K., Mouginot, J., and Fausto, R. S.: Greenland Ice Sheet solid ice discharge from 1986 through 2017, Earth Syst. Sci. Data, 11, 769-786, https://doi.org/10.5194/essd-11-769-2019, 2019.

Mankoff, K. D., Solgaard, A., Colgan, W., Ahlstrøm, A. P., Khan, S. A., and Fausto, R. S.: Greenland Ice Sheet solid ice discharge from 1986 through March 2020, Earth Syst. Sci. Data, 12, 13671383, https://doi.org/10.5194/essd-12-1367-2020, 2020.

Martin Bland, J. and Altman, D. G.: Statistical methods for assessing agreement between two methods of clinical measurement, Lancet, 327, 307-310, https://doi.org/10.1016/s01406736(86)90837-8, 1986.

McKinney, W.: Data Structures for Statistical Computing in Python, in: Proceedings of the 9th Python in Science Conference, edited by: van der Walt, S. and Millman, J., 28 June-3 July, Austin, Texas, 51-56, 2010.

Mernild, S. H. and Liston, G. E.: Greenland Freshwater Runoff. Part II: Distribution and Trends, 1960-2010, J. Climate, 25, 60156035, https://doi.org/10.1175/JCLI-D-11-00592.1, 2012.

Mernild, S. H., Liston, G. E., Hiemstra, C. A., and Steffen, K.: Surface melt area and water balance modeling on the Greenland ice sheet 1995-2005, J. Hydrometeorol., 9, 1191-1211, https://doi.org/10.1175/2008JHM957.1, 2008.

Mernild, S. H., Liston, G. E., Hiemstra, C. A., Steffen, K., Hanna, E., and Christensen, J. H.: Greenland Ice Sheet surface mass-balance modelling and freshwater flux for 2007, and in a 1995-2007 perspective, Hydrol. Process., 23, 2470-2484, https://doi.org/10.1002/hyp.7354, 2009.

Mernild, S. H., Howat, I. M., Ahn, Y., Liston, G. E., Steffen, K., Jakobsen, B. H., Hasholt, B., Fog, B., and van As, D.: Freshwater flux to Sermilik Fjord, SE Greenland, The Cryosphere, 4, 453465, https://doi.org/10.5194/tc-4-453-2010, 2010a.

Mernild, S. H., Liston, G. E., Steffen, K., van den Broeke, M., and Hasholt, B.: Runoff and mass-balance simulations from the Greenland Ice Sheet at Kangerlussuaq (Søndre Strømfjord) in a 30-year perspective, 1979-2008, The Cryosphere, 4, 231-242, https://doi.org/10.5194/tc-4-231-2010, 2010b.

Mernild, S. H., Liston, G. E., van As, D., Hasholt, B., and Yde, J. C.: High-resolution ice sheet surface massbalance and spatiotemporal runoff simulations: Kangerlussuaq, west Greenland, Arct. Antarct. Alp. Res., 50, S100008, https://doi.org/10.1080/15230430.2017.1415856, 2018.

Monteban, D., Pedersen, J. O. P., and Nielsen, M. H.: Physical oceanographic conditions and a sensitivity study on meltwater runoff in a West Greenland fjord: Kangerlussuaq, Oceanologia, 62, 460-477, https://doi.org/10.1016/j.oceano.2020.06.001, 2020.

Moon, T., Sutherland, D. A., Carroll, D., Felikson, D., Kehrl, L., and Straneo, F.: Subsurface iceberg melt key to Greenland fjord freshwater budget, Nat. Geosci., 11, 49-54, https://doi.org/10.1038/s41561-017-0018-z, 2017.

Morlighem, M., Williams, C., Rignot, E., An, L., Arndt, J. E., Bamber, J., Catania, G., Chauché, N., Dowdeswell, J. A., Dorschel, B., Fenty, I., Hogan, K., Howat, I., Hubbard, A., Jakobsson, M., Jordan, T. M., Kjeldsen, K. K., Millan, R., Mayer, L., Mouginot, J., Noël, B., O'Cofaigh, C., Palmer, S. J., Rysgaard, S., Seroussi, H., Siegert, M. J., Slabon, P., Straneo, F., van den Broeke, M. R., Weinrebe, W., Wood, M., and 
Zinglersen, K.: IceBridge BedMachine Greenland, Version 3, https://doi.org/10.5067/2CIX82HUV88Y (last access: 28 October 2018), 2017a.

Morlighem, M., Williams, C. N., Rignot, E., An, L., Arndt, J. E., Bamber, J. L., Catania, G., Chauché, N., Dowdeswell, J. A., Dorschel, B., Fenty, I., Hogan, K., Howat, I. M., Hubbard, A., Jakobsson, M., Jordan, T. M., Kjeldsen, K. K., Millan, R., Mayer, L., Mouginot, J., Noël, B. P. Y., Cofaigh, C. Ó., Palmer, S., Rysgaard, S., Seroussi, H., Siegert, M. J., Slabon, P., Straneo, F., van den Broeke, M. R., Weinrebe, W., Wood, M., and Zinglersen, K. B.: BedMachine v3: Complete bed topography and ocean bathymetry mapping of Greenland from multi-beam echo sounding combined with mass conservation, Geophys. Res. Lett., 44, 11051-11061, https://doi.org/10.1002/2017gl074954, 2017b.

Mortensen, J., Bendtsen, J., Motyka, R. J., Lennert, K., Truffer, M., Fahnestock, M., and Rysgaard, S.: On the seasonal freshwater stratification in the proximity of fast-flowing tidewater outlet glaciers in a sub-Arctic sill fjord, J. Geophys. Res.-Oceans, 118, 1382-1395, https://doi.org/10.1002/jgrc.20134, 2013.

Munneke, P. K., Ligtenberg, S. R. M., van den Broeke, M. R., van Angelen, J. H., and Forster, R. R.: Explaining the presence of perennial liquid water bodies in the firn of the Greenland Ice Sheet, Geophys. Res. Lett., 41, 476-483, https://doi.org/10.1002/2013GL058389, 2014.

Neteler, M., Bowman, M. H., Landa, M., and Metz, M.: GRASS GIS: a multi-purpose Open Source GIS, Environ. Modell. Softw., 31, 124-130, https://doi.org/10.1016/j.envsoft.2011.11.014, 2012.

Noël, B., van de Berg, W. J., Machguth, H., Lhermitte, S., Howat, I., Fettweis, X., and van den Broeke, M. R.: A daily, $1 \mathrm{~km}$ resolution data set of downscaled Greenland ice sheet surface mass balance (1958-2015), The Cryosphere, 10, 2361-2377, https://doi.org/10.5194/tc-10-2361-2016, 2016.

Noël, B., van de Berg, W. J., van Wessem, J. M., van Meijgaard, E., van As, D., Lenaerts, J. T. M., Lhermitte, S., Kuipers Munneke, P., Smeets, C. J. P. P., van Ulft, L. H., van de Wal, R. S. W., and van den Broeke, M. R.: Modelling the climate and surface mass balance of polar ice sheets using RACMO2 Part 1: Greenland (1958-2016), The Cryosphere, 12, 811-831, https://doi.org/10.5194/tc-12-811-2018, 2018.

Noël, B., van de Berg, W. J., Lhermitte, S., and van den Broeke, M. R.: Rapid ablation zone expansion amplifies north Greenland mass loss, Sci. Adv., 5, eaaw0123, https://doi.org/10.1126/sciadv.aaw0123, 2019.

Oliphant, T. E.: A guide to NumPy, vol. 1, Trelgol Publishing, USA, 2006.

Perner, K., Moros, M., Otterå, O. H., Blanz, T., Schneider, R. R., and Jansen, E.: An oceanic perspective on Greenland's recent freshwater discharge since 1850, Sci. Rep.-UK, 9, 17680, https://doi.org/10.1038/s41598-019-53723-z, 2019.

Pitcher, L. H., Smith, L. C., Gleason, C. J., and Yang, K.: CryoSheds: a GIS modeling framework for delineating land-ice watersheds for the Greenland Ice Sheet, GISci. Remote Sens., 53, 707-722, https://doi.org/10.1080/15481603.2016.1230084, 2016.

Porter, C., Morin, P., Howat, I., Noh, M.-J., Bates, B., Peterman, K., Keesey, S., Schlenk, M., Gardiner, J., Tomko, K., Willis, M., Kelleher, C., Cloutier, M., Husby, E., Foga, S., Nakamura, H., Platson, M., Wethington, Michael, J., Williamson, C., Bauer,
G., Enos, J., Arnold, G., Kramer, W., Becker, P., Doshi, A., D'Souza, C., Cummens, P., Laurier, F., and Bojesen, M.: ArcticDEM, https://doi.org/10.7910/DVN/OHHUKH (last access: 14 November 2019), 2018.

PROJ contributors: PROJ coordinate transformation software library, Open Source Geospatial Foundation, available at: https: //proj4.org/ (last access: 13 August 2020), 2018.

Rennermalm, A. K., Smith, L. C., Chu, V. W., Box, J. E., Forster, R. R., Van den Broeke, M. R., Van As, D., and Moustafa, S. E.: Evidence of meltwater retention within the Greenland ice sheet, The Cryosphere, 7, 1433-1445, https://doi.org/10.5194/tc7-1433-2013, 2013.

Rocklin, M.: Dask: Parallel Computation with Blocked algorithms and Task Scheduling, in: Proceedings of the 14th Python in Science Conference, edited by: Huff, K. and Bergstra, J., 6-12 July 2015, Austin, Texas, 130-136, https://doi.org/10.25080/Majora7b98e3ed-013, 2015.

Sasgen, I., Wouters, B., Gardner, A. S., King, M. D., Tedesco, M., Landerer, F. W., Dahle, C., Save, H., and Fettweis, X.: Return to rapid ice loss in Greenland and record loss in 2019 detected by the GRACE-FO satellites, Commun. Earth Environ., 1, 8, https://doi.org/10.1038/s43247-020-0010-1, 2020.

Schulte, E., Davison, D., Dye, T., and Dominik, C.: A multilanguage computing environment for literate programming and reproducible research, J. Stat. Softw., 46, 1-24, 2012.

Schulzweida, U.: CDO User Guide, Zenodo, https://doi.org/10.5281/zenodo.3539275, 2019.

Sergienko, O. V.: Glaciological twins: basally controlled subglacial and supraglacial lakes, J. Glaciol., 59, 3-8, https://doi.org/10.3189/2013JoG12J040, 2013.

Shreve, R. L.: Movement of water in glaciers, J. Glaciol., 11, 205214, 1972.

Slater, D. A., Straneo, F., Felikson, D., Little, C. M., Goelzer, H., Fettweis, X., and Holte, J.: Estimating Greenland tidewater glacier retreat driven by submarine melting, The Cryosphere, 13, 2489-2509, https://doi.org/10.5194/tc-13-2489-2019, 2019.

Smith, L. C., Chu, V. W., Yang, K., Gleason, C. J., Pitcher, L. H., Rennermalm, A. K., Legleiter, C. J., Behar, A. E., Overstreet, B. T., Moustafa, S. E., Tedesco, M., Forster, R. R., LeWinter, A. L., Finnegan, D. C., Sheng, Y., and Balog, J.: Efficient meltwater drainage through supraglacial streams and rivers on the southwest Greenland ice sheet, P. Natl. Acad. Sci. USA, 112, 1001-1006, https://doi.org/10.1073/pnas.1413024112, 2015.

Stallman, R. M.: EMACS the extensible, customizable selfdocumenting display editor, Proceedings of the ACM SIGPLAN SIGOA symposium on Text manipulation, 8-10 June 1981, Portland, Oregon, USA, 147-156, https://doi.org/10.1145/800209.806466, 1981.

Stevens, L. A., Hewitt, I. J., Das, S. B., and Behn, M. D.: Relationship Between Greenland Ice Sheet Surface Speed and Modeled Effective Pressure, J. Geophys. Res.-Earth, 123, 2258-2278, https://doi.org/10.1029/2017jf004581, 2018.

Straneo, F., Curry, R. G., Sutherland, D. A., Hamilton, G. S., Cenedese, C., Våge, K., and Stearns, L. A.: Impact of fjord dynamics and glacial runoff on the circulation near Helheim Glacier, Nat. Geosci., 4, 322-327, https://doi.org/10.1038/NGEO1109, 2011.

Sugiyama, S., Sakakibara, D., Matsuno, S., Yamaguchi, S., Matoba, S., and Aoki, T.: Initial field observations on Qaanaaq 
ice cap, northwestern Greenland, Ann. Glaciol., 55, 25-33, https://doi.org/10.3189/2014aog66a102, 2014.

Tange, O.: GNU Parallel - The Command-Line Power Tool, ;login: USENIX Magazine, 36, 42-47, https://doi.org/10.5281/zenodo.16303, 2011.

Tedstone, A., Bartholomew, I., Chandler, D., Cowton, C., Mair, D., Sole, A., Wadham, J., and Nienow, P.: Proglacial discharge measurements, Leverett Glacier, south-west Greenland (2009-2012), https://doi.org/10.5285/17c400f1-ed6d-4d5aa51f-aad9ee61ce3d, 2017.

Trusel, L. D., Das, S. B., Osman, M. B., Evans, M. J., Smith, B. E., Fettweis, X., McConnell, J. R., Noël, B. P. Y., and van den Broeke, M. R.: Nonlinear rise in Greenland runoff in response to post-industrial Arctic warming, Nature, 564, 104-108, https://doi.org/10.1038/s41586-018-0752-4, 2018.

van As, D., Hubbard, A. L., Hasholt, B., Mikkelsen, A. B., van den Broeke, M. R., and Fausto, R. S.: Large surface meltwater discharge from the Kangerlussuaq sector of the Greenland ice sheet during the record-warm year 2010 explained by detailed energy balance observations, The Cryosphere, 6, 199-209, https://doi.org/10.5194/tc-6-199-2012, 2012.

van As, D., Bech Mikkelsen, A., Holtegaard Nielsen, M., Box, J. E., Claesson Liljedahl, L., Lindbäck, K., Pitcher, L., and Hasholt, B.: Hypsometric amplification and routing moderation of Greenland ice sheet meltwater release, The Cryosphere, 11, 1371-1386, https://doi.org/10.5194/tc-11-1371-2017, 2017.

van As, D., Hasholt, B., Ahlstrøm, A. P., Box, J. E., Cappelen, J., Colgan, W., Fausto, R. S., Mernild, S. H., Mikkelsen, A. B., Noël, B. P. Y., Petersen, D., and van den Broeke, M. R.: Reconstructing Greenland Ice Sheet meltwater discharge through the Watson River (1949-2017), Arct. Antarct. Alp. Res., 50, S100010. https://doi.org/10.1080/15230430.2018.1433799, 2018.
Van Rossum, G. and Drake Jr., F. L.: Python reference manual, Centrum voor Wiskunde en Informatica Amsterdam, 1995.

Vandecrux, B., MacFerrin, M., Machguth, H., Colgan, W. T., van As, D., Heilig, A., Stevens, C. M., Charalampidis, C., Fausto, R. S., Morris, E. M., Mosley-Thompson, E., Koenig, L., Montgomery, L. N., Miège, C., Simonsen, S. B., Ingeman-Nielsen, T., and Box, J. E.: Firn data compilation reveals widespread decrease of firn air content in western Greenland, The Cryosphere, 13, 845-859, https://doi.org/10.5194/tc-13-845-2019, 2019.

Werder, M. A., Hewitt, I. J., Schoof, C. G., and Flowers, G. E.: Modeling channelized and distributed subglacial drainage in two dimensions, J. Geophys. Res., 118, 2140-2158, https://doi.org/10.1002/jgrf.20146, 2013.

Yang, K. and Smith, L. C.: Internally drained catchments dominate supraglacial hydrology of the southwest Greenland Ice Sheet, J. Geophys. Res.-Earth, 121, 1891-1910, https://doi.org/10.1002/2016jf003927, 2016.

Yang, K., Smith, L. C., Fettweis, X., Gleason, C. J., Lu, Y., and Li, M.: Surface meltwater runoff on the Greenland ice sheet estimated from remotely sensed supraglacial lake infilling rate, Remote Sens. Environ., 234, 111459 , https://doi.org/10.1016/j.rse.2019.111459, 2019.

Zender, C. S.: Analysis of self-describing gridded geoscience data with netCDF Operators (NCO), Environ. Modell. Softw., 23, 1338-1342, https://doi.org/10.1016/j.envsoft.2008.03.004, 2008.

Zuo, Z. and Oerlemans, J.: Modelling albedo and specific balance of the Greenland ice sheet: calculations for the SØndre StrØmfjord transect, J. Glaciol., 42, 305-317, https://doi.org/10.3189/s0022143000004160, 1996. 